\title{
REVIEW
}

\section{Growth hormone: roles in female reproduction}

\author{
K L Hull and S Harvey ${ }^{\mathbf{1}}$ \\ Bishop's University, Lennoxville, Quebec J1M 1Z7, Canada \\ ${ }^{1}$ Department of Physiology, University of Alberta, Edmonton, Alberta T6G 2H7, Canada \\ (Requests for offprints should be addressed to S Harvey, Department of Physiology, University of Alberta, Edmonton, Alberta T6G 2H7, Canada)
}

\begin{abstract}
$\mathrm{GH}$, as its name suggests, is obligatory for growth and development. It is, however, also involved in the processes of sexual differentiation and pubertal maturation and it participates in gonadal steroidogenesis, gametogenesis and ovulation. It also has additional roles in pregnancy and lactation. These actions may reflect direct endocrine actions of pituitary GH or be mediated by its induction of
\end{abstract}

hepatic or local IGF-I production. However, as GH is also produced in gonadal, placental and mammary tissues, it may act in paracrine or autocrine ways to regulate local processes that are strategically regulated by pituitary GH. The concept that GH is an important modulator of female reproduction is the focus of this review.

Journal of Endocrinology (2001) 168, 1-23

\section{Introduction}

Although the somatogenic and gonadotrophic axes have long been known to be closely linked during growth and sexual maturation (Simpson et al. 1944), until recently the role of growth hormone $(\mathrm{GH})$ in reproduction had been described as 'more akin to fine tuning than that of a major player ...' (Ogilvy-Stuart \& Shalet 1992). Experimental studies suggest, however, that this statement underestimates the importance of $\mathrm{GH}$ in reproductive function, since GH modulates steroidogenesis, gametogenesis and gonadal differentiation as well as gonadotrophin secretion and responsiveness (Zachmann 1992). Mammary and placental roles for GH have also been proposed ( $\mathrm{Mol}$ et al. 1996, Alsat et al. 1997). Moreover, while these actions may reflect endocrine roles of pituitary $\mathrm{GH}$, they may also reflect local autocrine or paracrine actions of $\mathrm{GH}$ produced in reproductive tissues (Fig. 1).

\section{Puberty}

$\mathrm{GH}$ is usually, but not always, required for the timing of sexual maturation, since delayed or absent puberty is often associated with GH-deficient or GH-resistant states and $\mathrm{GH}$ administration accelerates puberty. For instance, in a cohort of $60 \mathrm{GH}$-deficient women, puberty occurred normally in only 16 and was delayed in 10 others (de Boer et al. 1997). Puberty is similarly delayed in a large proportion of GH receptor (GHR)-knockout mice (Bartke et al. 1999), GH-resistant women (Laron 1984) and GH-releasing hormone (GHRH)-immunized cattle
(Simpson et al. 1991). The importance of GH in sexual maturation is further demonstrated by the ability of exogenous $\mathrm{GH}$ to accelerate sexual maturation in $\mathrm{GH}-$ replete monkeys (Wilson et al. 1989) and GH-deficient children (Darendeliler et al. 1990, Stanhope et al. 1992). GH may accelerate puberty by activating the luteinizing hormone (LH)-releasing hormone pulse generator (Bartke et al. 1999) and/or by potentiating androgen action (Ilondo et al. 1982).

GH administration has not, however, been shown to accelerate pubertal development in pigs (Bryan et al. 1989, 1990, Andres et al. 1991). This may, however, reflect the reproductive state at the time of $\mathrm{GH}$ treatment, since $\mathrm{GH}$ appears to increase the rate of human sexual maturation only when a pubertal pattern of pituitary gonadotrophin secretion is established (Sharara \& Giudice 1997). Moreover, since the implantation of bovine $\mathrm{GH}(\mathrm{bGH})$ in the median eminence of young female rats delays puberty (Advis et al. 1981), it is possible that GH exerts inhibitory effects on the hypothalamo-pituitary-gonadal axis at central sites, contrary to its stimulatory actions on pituitary gonadal function.

\section{Ovarian Actions}

Experimental studies performed in vivo suggest that $\mathrm{GH}$ acts on the ovary to affect gametogenesis and steroidogenesis. The interpretation of these in vivo studies is, however, complicated by the increase in circulating insulin-like growth factor-I (IGF-I) resulting from in vivo 


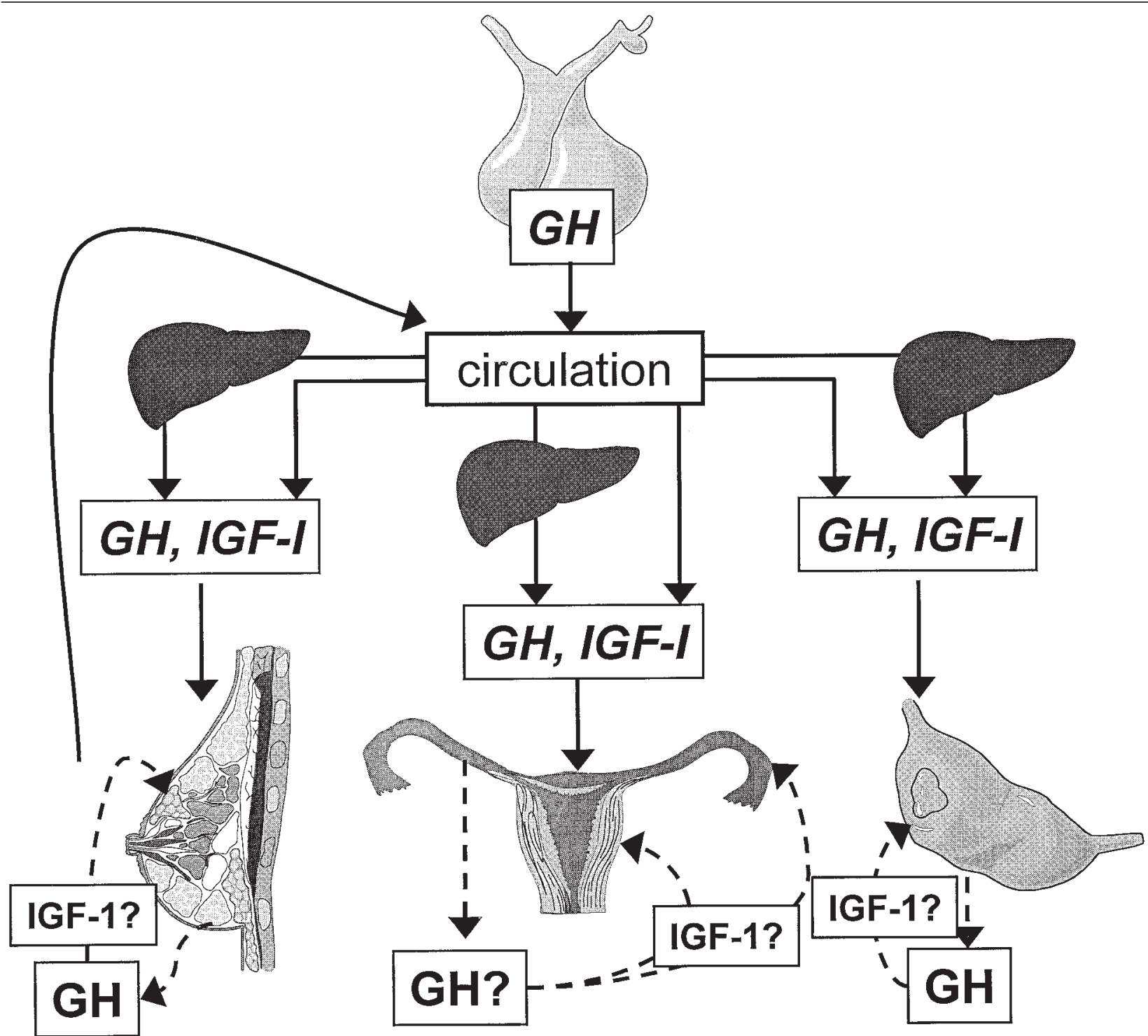

Figure 1 Effects of $\mathrm{GH}$ in the female reproductive system. Pituitary GH stimulates the production of hepatic IGF-I, and both pituitary GH and hepatic IGF-I act to stimulate mammary, ovarian, uterine and/or oviduct function. However, GH is also produced in the mammary gland, placenta, ovary and perhaps oviduct, and may act directly or via local IGF-I to affect reproductive function. Pituitary GH and hepatic IGF-I may be involved in strategic maintenance of ovarian function (italic text, solid lines), whereas ovarian GH may be involved in emergency modulation of ovarian function (normal text, dotted lines).

GH administration and the proven ability of IGF-I to stimulate ovarian activity (Adashi et al. 1985). Indeed, the administration of exogenous $\mathrm{GH}$ results in an artificial situation in which both GH and IGF-I are elevated, whereas physiological increases in IGF-I normally result in a decrease in pituitary GH production. In vivo responses are thus likely to partially reflect the actions of $\mathrm{GH}-$ induced hepatic IGF-I. Numerous in vitro studies and the finding of GHR mRNA and protein in ovarian cells suggest, however, that direct ovarian actions of $\mathrm{GH}$ provide an important modulation of gonadotrophindependent and -independent functions.

\section{Folliculogenesis and gametogenesis}

The production of viable gametes and adequate steroid production requires a series of developmental events to occur in the follicle (Fig. 2) and within the oocyte. GH affects the maturation of the follicle and gamete and thereby plays a facilitatory role in fertility.

Early folliculogenesis GH may play a particularly important role in early, follicle-stimulating hormone (FSH)-independent follicular development (Fig. 2), since GH-binding activity peaks during early folliculogenesis in porcine follicles (Quesnel 1999) and fish ovarian 


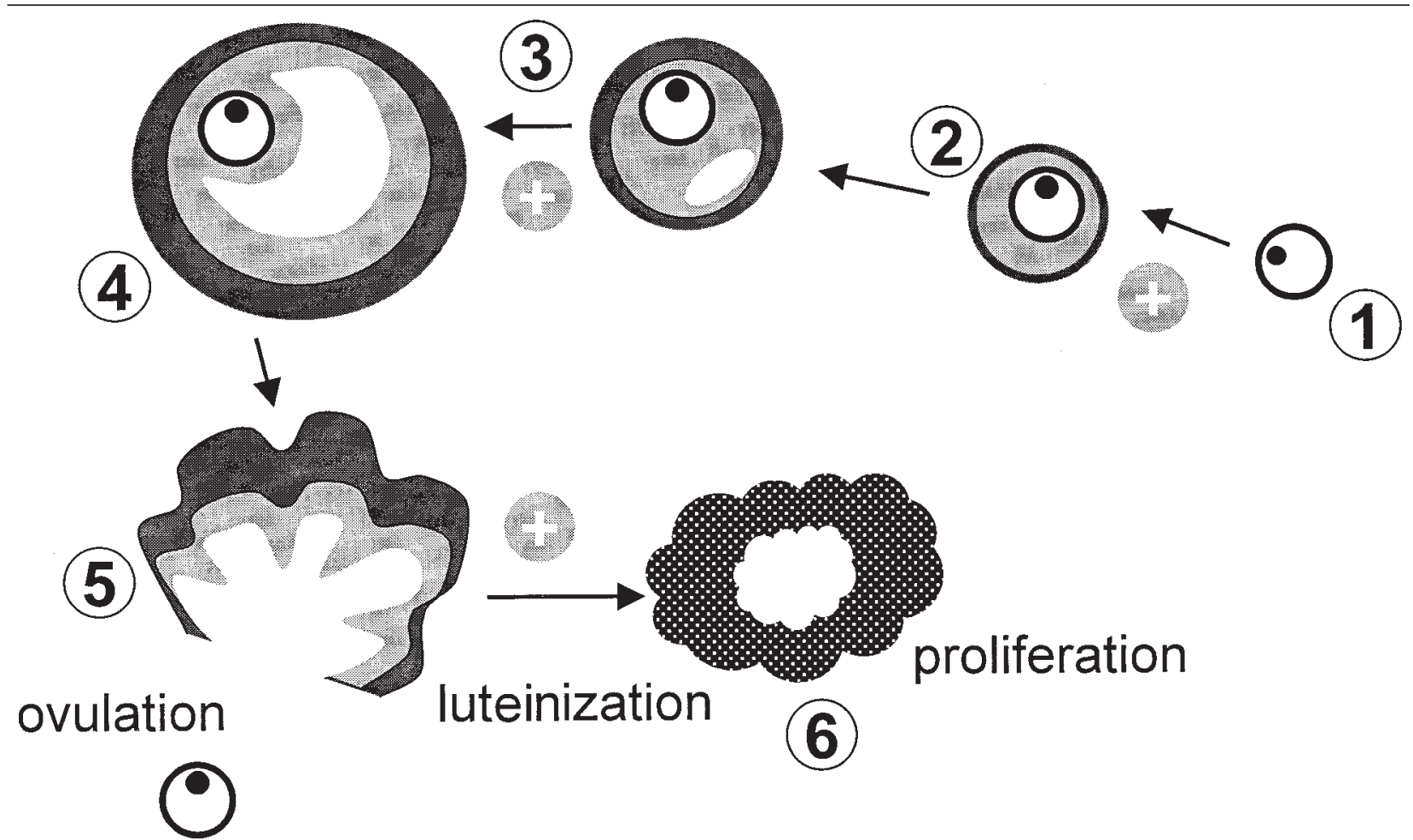

Figure 2 Role of GH in gametogenesis. Primary follicles (stage 1) develop into preantral follicles (stage 2) and possibly small antral follicles (stage 3) independently of FSH. A certain number of these small follicles (stages 2 and 3) undergo further FSH-dependent development each menstrual cycle into mature antral (Graafian) follicles (stage 4) prior to ovulation (stage 5) or apoptosis. These stages of folliculogenesis are characterized by increasing numbers of granulosa cells (grey) and thecal cells (black), both of which are required for the production of oestrogen. After the oocyte is expelled from the follicle, granulosa cells and, to a lesser extent, thecal cells, become luteinized (6), and acquire the ability to synthesize progesterone. GH of pituitary and/or ovarian origin binds GHRs on thecal, granulosa and luteal cells and promotes gametogenesis (+). Some of the ovarian actions of GH are modulated by ovarian and/or hepatic IGF-I (not shown; Table 1).

homogenates (Gomez et al. 1998). Indeed, in vivo and in vitro studies suggest that $\mathrm{GH}$ stimulates growth and prevents atresia in small follicles, which develop and undergo atresia throughout the menstrual cycle. For instance, GH administration in vivo increases the number of small follicles in cattle (Gong et al. 1991, 1993) and horses (Cochran et al. 1999). In vitro studies in mice, accordingly, show a stimulatory effect of $\mathrm{GH}$ on preantral follicle development and follicular cell proliferation in immature mice that is synergistic with (and therefore independent of) IGF-I (Kumar et al. 1997, Liu et al. 1998, Kobayashi et al. 2000). Other studies in perifused rabbit ovaries, however, implicate IGF-I in early folliculogenesis, since follicular growth and intraovarian IGF-I increase in a coordinate fashion following $\mathrm{GH}$ administration (Yoshimura et al. 1993, 1994). Other ovarian growth factors, such as activin, may also mediate the actions of $\mathrm{GH}$, since folliculostatin (which binds and inactivates activin) blocks the stimulatory effect of $\mathrm{GH}$ on murine preantral follicle growth (Liu et al. 1998). GH may thus be particularly important in the recruitment of follicles and initiation of oocyte growth, perhaps by matching nutritional status with the number of growing oocytes.
Late folliculogenesis and luteinization GH acts in conjunction with gonadotrophins to stimulate later stages of folliculogenesis and luteinization (Fig. 2), since both GH and gonadotrophins are required to prevent atresia of larger follicles $(>2 \mathrm{~mm})$ following hypophysectomy in sheep (Eckery et al. 1997). GH may play a role in follicle selection, since $\mathrm{GH}$-binding sites in sow granulosa cells are lost in atretic follicles (Quesnel 1999) and the development of the dominant follicle is impaired in GHRdeficient cattle (Chase et al. 1998). GH administration in vivo similarly increases the number of large follicles in pigs (DeLaSota et al. 1993, Lucy et al. 1995) and GH-deficient dwarf rats (Ozawa et al. 1996) and the number of corpora lutea in cattle (Lucy et al. 1992) and GH transgenic rats (Danilovich et al. 2000). The stimulatory effect of GH on follicle number and size reflects increased cell proliferation, at least in luteinized human granulosa cells (Ovesen et al. 1994), but also is indicative of the suppressive effect of GH on apoptosis (Eisenhauer et al. 1995, Sirotkin \& Makarevich 1999, Danilovich et al. 2000). GH may enhance follicular survival and cell proliferation by potentiating LH action, since GH deficiency is associated with decreased $\mathrm{LH}$ receptor gene expression and $\mathrm{LH}$ 
responsiveness in rats and $\mathrm{GH}$ administration corrects both defects (Advis et al. 1981). The folliculogenic effect of GH, at least in human luteinized granulosa cells, is dependent upon FSH and independent of IGF-I (Ovesen et al. 1994, Ovesen 1998).

Oocyte maturation An important role for GH in the development of the oocyte is indicated by the relationship between follicular GH concentrations and human oocyte maturity (Mendoza et al. 1999). Oocytes harvested from follicles with high antral fluid GH concentrations are more fertile than those from follicles with low GH concentrations, and amongst fertilized oocytes, intrafollicular $\mathrm{GH}$ concentration is inversely related to subsequent cleavage failures and morphological dysfunctions of the cleaved embryos (Mendoza et al. 1999). In contrast, prolactin, LH, interleukin-1 and tumour necrosis factor- $\alpha$ are unrelated to the development of competent oocytes (Mendoza et al. 1999). Mendoza et al. (1999) have therefore concluded that an early rise in the $\mathrm{GH}$ concentration in small antral follicles is beneficial for oocyte quality, by enhancing or acting in synergy with gonadotrophin-controlled developmental processes. Accordingly, the fertilization rate in bovine oocytes in vitro is increased by incubation with $\mathrm{GH}$ (Izadyar et al. 1998).

GH may enhance oocyte quality by accelerating and coordinating cytoplasmic and nuclear maturation, at least in bovine oocytes. This possibility is indicated by the greater proportion of bovine oocytes manifesting the markers of cytoplasmic maturation (for instance, the ability to decondense sperm chromatin and form sperm asters (Hyttel et al. 1989)) in GH-treated cell populations (Izadyar et al. 1997, 1998). Nuclear maturation is similarly enhanced by $\mathrm{GH}$, since $\mathrm{GH}$-treated bovine oocytes complete meiosis I faster and undergo zygote cleavage and blastocyst formation more frequently than untreated oocytes (Van der Westerlaken et al. 1994, Izadyar et al. 1996, 1998). This effect of GH is dependent upon cAMP and the presence of cumulus cells but is IGF-Iindependent (Bevers et al. 1989, Zuelke \& Brackett 1993, Izadyar et al. 1997, 1998, Kolle et al. 1998). GHR mRNA and protein are, moreover, not detected in oocytes from secondary or tertiary follicles of the bovine ovary (Kolle et al. 1998); thus, direct actions at the oocyte itself appear unlikely. GH also stimulates nuclear maturation of fox, rat, rabbit and pig oocytes; however, at least in rats, cumulus cell IGF-I appears to be the mediator and cAMP is not involved (Hagen \& Graboski 1990, Yoshimura et al. 1993, 1994, Apa et al. 1994b, Kalous et al. 1998).

Ovulation $\mathrm{H}$ plays a non-essential but facilitatory role in ovulation. For instance, although GH alone fails to cause ovulation in sheep (Davis et al. 1990), pigs (Gilbertson et al. 1991) or rabbits (Yoshimura et al. 1993), gonadotrophininduced ovulation in perifused rabbit ovaries is significantly improved by GH co-administration (Yoshimura et al.
1994). Moreover, fertility is reduced but not abolished in GHR-knockout mice (Bartke 1999) and egg production and fertility are not impaired in GH-resistant sex-linked dwarf chickens (Decuypere et al. 1991). In such cases, other GH-like hormones, particularly prolactin, may compensate for the lack of GH action (Bartke 1999). Indeed, unlike GHR-knockout mice, Snell and Ames mice are totally sterile, lacking $\mathrm{GH}$, prolactin and thyrotrophin (Bartke 1999).

GH may facilitate ovulation by increasing sensitivity to gonadotrophins and by reducing the incidence of apoptosis in preovulatory ovarian follicles. The increased number of corpora lutea and reduced numbers of atretic follicles in the ovaries of mice transgenically expressing GH supports this view (Danilovich et al. 2000). The overexpression of GH in these mice has thus been correlated with an increase in the number of ova shed during each ovulation (Cecim et al. 1995, Danilovich et al. 2000). Since treatment with IGF-I also suppresses apoptotic DNA fragmentation in preovulatory follicles, this action of $\mathrm{GH}$ is thought to be IGF-I mediated (Danilovich et al. 2000). GH may also facilitate ovulation by increasing tissue plasminogen activator synthesis, which activates the serine protease required for rupture of the ovarian capsule (Politis et al. 1990).

The timing of ovulation may also be GH-dependent, since it is delayed in normal female mice paired with GHR-knockout mice (Bartke et al. 1999). A reduced secretion of the male pheromones responsible for synchronizing the ovulatory cycle in the female has been implicated (Bartke et al. 1999). In female GHR-knockout mice, the oestrous cycle is prolonged and irregular and the ovulation rate is reduced, resulting in smaller litters (Bartke et al. 1999, Danilovich et al. 1999).

Fertility: clinical studies Normal fertility does not always require a normal GH axis. Indeed, it is well established that a proportion of $\mathrm{GH}$-deficient (de Boer et al. 1997) and GH-resistant (Menashe et al. 1991, Dor et al. 1992) women have normal menstrual cycles and conceive normally. However, many GH-deficient women require assisted reproductive technologies to conceive, principally for the induction of ovulation, and it has been hypothesized that other women with reproductive dysfunctions may be partially GH-deficient (de Boer et al. 1997). The possible use of GH as an adjunct to human menopausal gonadotrophin (hMG) to induce ovulation has thus been the focus of extensive research (Jacobs 1992, Shoham et al. 1992a, Homburg \& Farhi 1995) and reviews (Katz et al. 1993, Homburg \& Farhi 1995, Franks 1998). Clinical studies have shown that GH may be therapeutically useful in some, but not all, infertile women. In particular, GH administration to hypogonadotrophic anovulatory women significantly reduces the dosage and duration of hMG treatment required for ovulation induction (Blumenfeld \& Lunenfeld 1989, Homburg et al. 1990, Volpe et al. 1990, Burger et al. 1991, Fowler \& Templeton 
1991, Jacobs 1992). Furthermore, a significant proportion of women who respond to $\mathrm{GH}$ fail to respond to $\mathrm{hMG}$ alone. $\mathrm{GH}$ administration also restores FSH responsiveness in women with Down's syndrome, as determined by serum oestradiol concentrations (Cento et al. 1997).

GH therapy may similarly improve the success of in vitro fertilization techniques by enhancing the hyperovulatory response to hMG. Numerous clinical studies have demonstrated that the addition of $\mathrm{GH}$ to the hMG treatment regimen improves oocyte recovery and/or the rate of successful fertilizations and pregnancies (Volpe et al. 1989, Ibrahim et al. 1991, Jacobs 1992, Stone \& Marrs 1992). Responsiveness to hMG in normogonadotrophic women with polycystic ovary syndrome is similarly improved by the administration of GH (Owen et al. 1991a,b). In initial studies that employed pharmacological doses of $\mathrm{GH}$, the improvement in fertility was thought to be partially due to the lipolytic action of $\mathrm{GH}$ and a reduction in obesity (Morales 1997). However, later studies suggested that much lower doses of GH are equally effective (Shoham et al. 1992b). Indeed, several investigators have suggested that a single $\mathrm{GH}$ injection enhances hMG responsiveness for several subsequent cycles (Homburg et al. 1990, Burger et al. 1991, Fowler \& Templeton 1991, Blumenfeld et al. 1992).

GH therapy does not, however, enhance gonadotrophic responsiveness in all women with infertility (Shaker et al. 1992, Tapanainen et al. 1992, Younis et al. 1992). Most of the women that do respond to GH-hMG co-treatment have an impairment in their secretion of GH (Blumenfeld et al. 1991). The infertility in these women may thus result in part from relative $\mathrm{GH}$ deficiency, whereas other dysfunctions are likely to be causal in the infertility of women that fail to respond to GH-hMG co-treatment (Blumenfeld et al. 1991). GH responsiveness is also greatest in young, hypo-oestrogenic women who have been subjected to previous pituitary suppression (Shaker et al. 1992, Tapanainen et al. 1992, Younis et al. 1992, Blumenfeld \& Amit 1993). Conversely, GH therapy is largely ineffective in hypergonadotrophic women (Homburg \& Farhi 1995) or women experiencing incipient or current ovarian failure (Homburg et al. 1991). Thyroid and adrenal function, and lifestyle characteristics, such as smoking, may also be important determinants in GH treatment efficacy (Hillensjo \& Bergh 1993). In vitro fertilization protocols using gonadotrophin-releasing hormone agonists in the treatment regimen usually report that GH improves fertilization rate but not oocyte retrieval (Bergh et al. 1994, Hughes et al. 1994). The lack of GH response in some patients may also reflect concomitant changes in follicular IGF-binding proteins (IGFBPs), which would negate the beneficial effect of $\mathrm{GH}$ on follicular IGF-I (Rabinovici et al. 1997).

\section{Summary}

A significant amount of literature supports a role for $\mathrm{GH}$ in the production of viable gametes, since GH modulates gonadotrophin-independent early folliculogenesis and gonadotrophin-dependent late folliculogenesis by increasing cell proliferation and inhibiting atresia. $\mathrm{GH}$ also increases oocyte fertility by enhancing nuclear and cytoplasmic maturation and facilitating ovulation. Ovarian and hepatic IGF-I appear to be involved in some, but not all, of these actions in some species. As a result of these gametogenic and folliculogenic actions, GH has been shown to influence fertility.

\section{Steroidogenesis}

The production of steroid hormones by ovarian cells is essential for follicular recruitment, oocyte maturation, ovulation, corpus luteal function, the maintenance and implantation of the blastocyst and the regulation of the hypothalamo-pituitary-gonadal axis. Steroidogenesis is therefore a prerequisite for successful reproduction. Although LH and FSH are the primary regulators of ovarian steroidogenesis, $\mathrm{GH}$ also modulates the production of ovarian steroids (Fig. 3).

In vivo studies The ovarian actions of $\mathrm{GH}$ are partly mediated by changes in ovarian steroidogenesis. This is indicated by the partial progesterone deficiency in GHRdeficient cattle (Chase et al. 1998). Plasma oestradiol-17 $\beta$ levels in female killifish are, moreover, increased by exogenous $\mathrm{GH}$, which also prevents the hypophysectomyinduced decline in gonadal weight (Singh et al. 1988). However, consistent changes in blood steroid concentrations in response to $\mathrm{GH}$ administration have been difficult to demonstrate. For instance, whereas Bryan et al. (1992) noted a stimulatory effect of GH administration on plasma oestradiol levels in pigs, Samaras et al. (1994) observed GH alone was ineffective and actually inhibited the gonadotrophin-induced rise in plasma oestradiol. Conversely, in GH-treated cattle, changes in progesterone but not oestradiol levels (Schemm et al. 1990, Gallo \& Block 1991), or in oestradiol but not progesterone (Andrade et al. 1996), or in neither hormone (Yuan \& Lucy 1996a) have been reported. GH administration also reduces plasma androgen concentrations in humans (Tapanainen et al. 1992, Volpe et al. 1992), but not in cattle (Andrade et al. 1996) or sheep (Scaramuzzi et al. 1999). This reduction may represent increased conversion of androgens into oestrogens, since GH enhances aromatase and $3 \beta$ hydroxysteroid dehydrogenase activity in women (Tapanainen et al. 1992). GH-induced changes in follicular steroid synthesis may be independent of IGF-I, since follicular fluid IGF-I levels can be increased without parallel increases in oestrogen or progesterone in pigs (Bryan et al. 1992, Samaras et al. 1994) or cows (Andrade et al. 1996).

In vitro studies Most, but not all, in vitro studies indicate a direct effect of $\mathrm{GH}$ on ovarian steroidogenesis. $\mathrm{GH}$ 


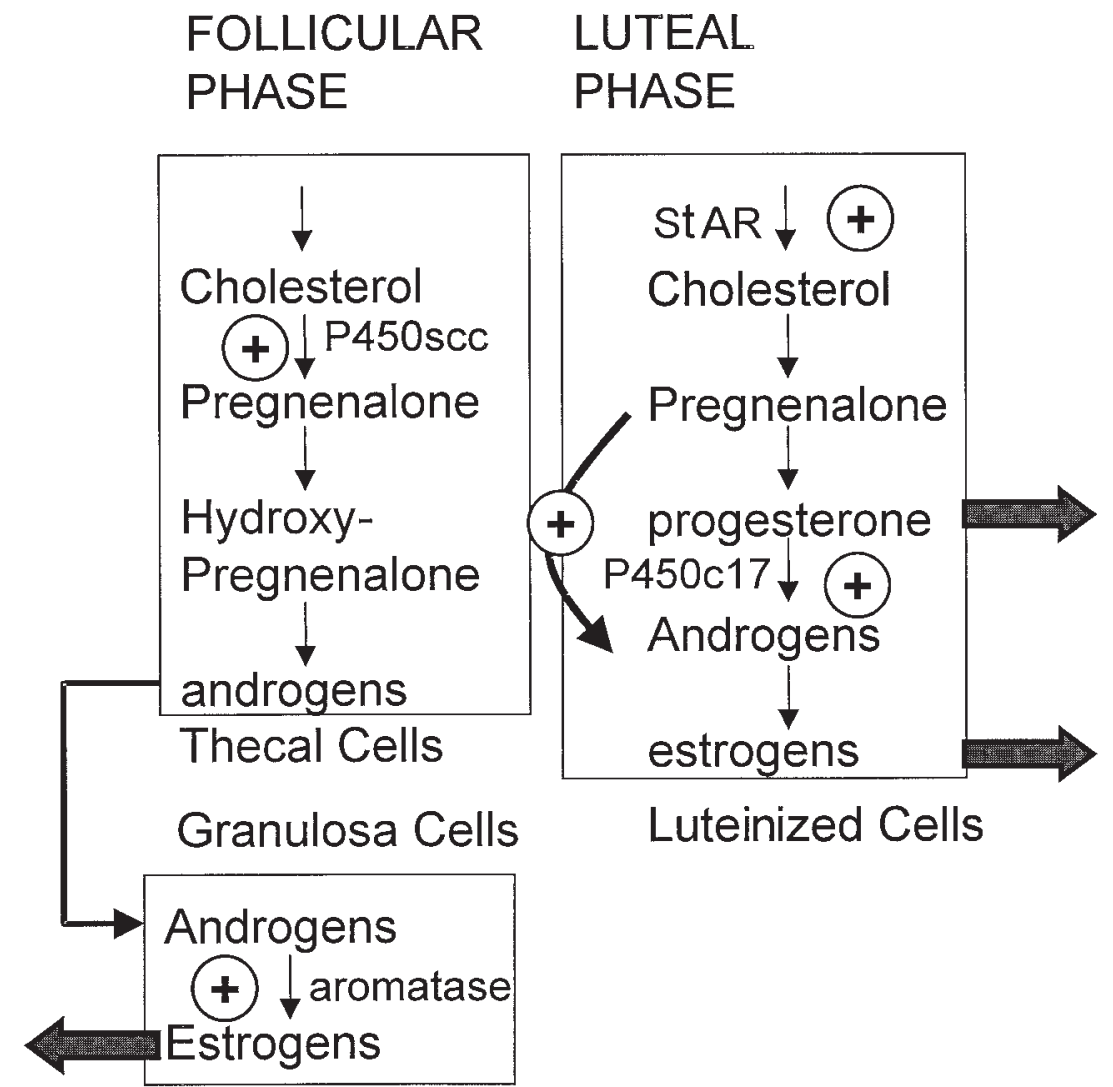

Figure 3 Role of $\mathrm{GH}$ in steroidogenesis. Thecal and granulosa cells interact during the follicular phase to synthesize oestrogens, which are secreted. Following ovulation, granulosa cells become luteinized and acquire the ability to synthesize and secrete both oestrogens and progesterone. Experimental studies described in the text have demonstrated that $\mathrm{GH}$ increases $(+)$ the activity of certain steroidogenic enzymes during the follicular and/or luteal phase, thereby increasing oestrogen or progesterone secretion. StAR is responsible for translocating cholesterol to the mitochondria for processing. The large, solid arrows indicate the release of newly synthesized steroids into interstitial fluid, from which they can access other ovarian cells or the bloodstream.

enhances oestradiol secretion from human granulosa cells (Mason et al. 1990, Ovesen et al. 1994, Doldi et al. 1996), perifused rabbit ovaries (Yoshimura et al. 1993), goldfish follicles (Van der Kraak et al. 1990) and bovine follicles (Sirotkin \& Nitray 1994, Sirotkin 1996, Sirotkin \& Makarevich 1999). Progesterone production from human (Lanzone et al. 1992, Doldi et al. 1996), rat (Jia et al. 1986, Hong \& Herington 1991, Apa et al. 1994a), bovine (Langhout et al. 1991, Spicer et al. 1993, Liebermann \& Schams 1994) and sheep (Wathes et al. 1995) luteal cells is similarly enhanced by GH. The steroidogenic effect of $\mathrm{GH}$, at least in fish, is equivalent to that of chorionic gonadotrophin (Singh \& Thomas 1993). Inhibitory or insignificant effects of $\mathrm{GH}$ on progesterone (Ovesen et al. (1994) in human; Yoshimura et al. (1993) and Ando et al. (1994) in rabbit; Sirotkin \& Nitray (1994) and Lucy et al. (1999) in cow) or oestradiol (Jia et al. (1986) in rat; Rajkumar et al. (1993) and Spicer \& Stewart (1996) in pig) levels have, however, been documented in other studies. $\mathrm{GH}$ responsiveness may be dependent on follicle size, since the stimulatory effect of $\mathrm{GH}$ on oestradiol synthesis in porcine granulosa cells was only observed in cells from small follicles (Spicer \& Echternkamp 1995).

GH may induce steroidogenesis by potentiating gonadotrophin action, since $\mathrm{GH}$ only stimulates oestradiol production from goldfish follicles (Van der Kraak et al. 1990) and progesterone production from rat follicles (Singh \& Thomas 1993) if gonadotrophins are present. In addition, GH stimulates androgen synthesis in LHresponsive, but not LH-resistant, bovine thecal cells (Spicer \& Stewart 1996). Other studies indicate that GH and gonadotrophins act synergistically to increase oestradiol synthesis in human granulosa cells (Carlsson et al. 1992, Lanzone et al. 1992) and progesterone synthesis in rat granulosa cells (Hsu \& Hammond 1987). This synergy may reflect upregulation of gonadotrophin receptors by 
Table 1 The involvement of IGF-I in the reproductive actions of GH

\author{
Dependent on local IGF-I \\ FSH-induced progesterone secretion in rat granulosa cells \\ Oestradiol secretion in human granulosa cells \\ Nuclear maturation in rat oocytes \\ Follicle growth in rabbit ovaries

\section{Independent of IGF-I} \\ Progesterone synthesis in porcine granulosa cells \\ Nuclear maturation in bovine oocytes \\ Cell growth in human follicles \\ Cell growth in mice preantral follicles
}

\section{Reference}

Hutchinson et al. (1988)

Barreca et al. (1993)

Apa et al. (1994b)

Yoshimura et al. (1994)

\author{
Mondschein et al. (1989) \\ Izadyar et al. (1997) \\ Ovesen (1998) \\ Liu et al. (1998)
}

GH or the upregulation of GHRs by gonadotrophininduced cAMP (Adashi et al. 1994). Indeed, at least in sheep, adequate ovarian GHR gene expression requires pituitary gonadotrophins (Juengel et al. 1997).

The stimulatory effects of $\mathrm{GH}$ on folliculogenesis and ovulation have obvious implications for steroidogenesis (Jia et al. 1986, Apa et al. 1994b). However, the steroidogenic effects of $\mathrm{GH}$ in some studies are too rapid to reflect cell differentiation and may instead reflect increased synthesis of steroidogenic enzymes (Fig. 3). For instance, GH stimulates steroidogenic acute regulatory protein (StAR) gene expression in the ovine corpus luteum (Juengel et al. 1995), facilitating the translocation of the cholesterol substrate to the mitochondrion for steroidogenic processing. GH also increases P450 side-chain cleavage (P450 $\mathrm{scc})$ gene expression in porcine granulosa cells (Xu et al. 1997a), increasing the conversion of cholesterol to pregnenalone. GH similarly increases P450c17 mRNA in luteinized human granulosa cells, thereby increasing dehydroepiandrostenedione production (Doldi et al. 1996). Basal and FSH-induced aromatase activity is also augmented by GH in human granulosa cells (Mason et al. 1990). GH also enhances aromatase activity and other unidentified steroidogenic enzymes involved in earlier stages of oestradiol synthesis in sea trout ovaries (Singh \& Thomas 1993).

$\mathrm{GH}$ may stimulate steroid synthesis in humans by IGF-I-dependent and -independent mechanisms. The paucity of IGF-I in human follicles (Mason et al. 1990, Ovesen et al. 1994), even those treated with GH, would suggest that IGF-I does not mediate steroidogenic effects of $\mathrm{GH}$ in humans. Indeed, IGF-I independence is also indicated by the synergistic effect of GH and IGF-I/ IGF-II on oestradiol production in human (Ovesen 1998) granulosa cells. However, IGF-I antibodies significantly inhibit GH effects on oestradiol production in human granulosa cells (Barreca et al. 1993). It has been hypothesized that GH may affect ovarian steroidogenesis by increasing the sensitivity to IGF-II acting through the IGF-I receptor, since IGF-II and IGFBPs are abundantly present in human granulosa cells but IGF-I is scarce (Barreca et al. 1993). It is, moreover, possible that GHinduced ovarian IGF-I may act in an autocrine or even intracrine way, which would not require IGF-I secretion into the medium in detectable quantities.

Studies in animals also postulate that GH stimulates steroidogenesis by both IGF-I-dependent and -independent mechanisms (Table 1). IGF-I antibodies cannot completely block GH-induced progesterone synthesis in porcine granulosa cells (Mondschein et al. 1989) or androgen synthesis by rat thecal-interstitial cells (Apa et al. 1996). Indeed, IGF-I is not even detected in follicles from GH-treated heifers (Spicer et al. 1993) and ewes (Wathes et al. 1995), despite increases in progesterone release. IGF-I-independence is also indicated by the synergistic effect of GH and IGF-I/IGF-II on oestradiol production in porcine (Xu et al. 1997b) granulosa cells. The existence of distinct signalling mechanisms for $\mathrm{GH}$ and IGF-I is further supported by the opposite effects of cortisol and transferrin on GH- and IGF-I-induced progesterone synthesis (Hong \& Herington 1991, Xu et al. 1995). This occurs by two distinct mechanisms, since cyanoketone treatment blocks bGH-induced oestradiol production but not bGH-induced conversion between testosterone and oestradiol (Singh \& Thomas 1993). Aromatase activity, is, conversely, blocked by protein synthesis inhibitors and may thus be increased by IGF-I-dependent mechanisms (Singh \& Thomas 1993).

Although GH signal transduction is normally mediated by the JAK2 cascade, cAMP may also be involved in $\mathrm{GH}$-induced steroidogenesis. This possibility is suggested by the coincident increases in cAMP, IGF-I, and oestradiol in GH-treated bovine granulosa cells and the ability of protein kinase A blockers to inhibit these $\mathrm{GH}$-induced changes (Sirotkin \& Makarevich 1996, Sirotkin \& Makarevich 1999). GH similarly induces cAMP production and subsequently steroid production in porcine (Sirotkin et al. 1998) and piscine (Van der Kraak et al. 1990) follicles and sea trout ovaries (Singh \& Thomas 
Table 2 GHRH and SRIF gene expression and immunoreactivity (IR) in female reproductive tissues. $(\mathrm{R}=$ receptor)

\begin{tabular}{|c|c|c|c|}
\hline & Ovary & Placenta & Mammary gland \\
\hline GHRH mRNA & Bagnato et al. (1992) & Mizobuchi et al. (1995) & Benlot et al. (1997) \\
\hline GHRH-IR & Bagnatao et al. (1992) & Berry et al. (1992) & Benlot et al. (1997) \\
\hline GHRHR mRNA/GHRHR-IR & Moretti et al. (1990a) & - & - \\
\hline SRIF mRNA/SRIF-IR & Mori et al. (1984) & Lee et al. (1982) & Benlot et al. (1997) \\
\hline SRIFR mRNA & Baumeister et al. (1998) & Caron et al. (1997) & - \\
\hline SRIFR-IR & - & Caron et al. (1997) & - \\
\hline
\end{tabular}

1993). In pigs, this effect is dependent upon protein synthesis and acts both proximally and distally to the generation of cAMP (Xu et al. 1997b). Conversely, GH stimulates progesterone synthesis in gonadotrophinprimed rat granulosa cells independently of cAMP accumulation and de novo protein synthesis (Apa et al. 1994a).

\section{Summary}

$\mathrm{GH}$ has been shown to affect progesterone and oestrogen synthesis both in vivo and in vitro. The steroidogenic action of $\mathrm{GH}$ is associated with increased activity of several enzymes and may be partially responsible for the facilitatory effect of $\mathrm{GH}$ on folliculogenesis and gametogenesis.

\section{The ovarian mini-hypophysis}

GH synthesis Ovarian steroidogenesis and gametogenesis may be regulated by locally produced $\mathrm{GH}$ as well as pituitary $\mathrm{GH}$ (Fig. 1), since low levels of $\mathrm{GH}$ gene transcripts and proteins are present in the human ovary (Schwarzler et al. 1997). Granulosa cells and oocytes in particular may be regulated by local GH, since granulosa cells are avascular and separated from systemic circulation by the basal lamina (Lobie et al. 1992).

The synthesis of $\mathrm{GH}$ within the ovary may be regulated by locally produced GH secretagogues, since GHRH and GHRH receptors are abundantly present in ovarian tissues (Moretti et al. 1990b) (Table 2). Somatostatin (SRIF) immunoreactivity and SRIF receptors are similarly present (Mori et al. 1984, Baumeister et al. 1998) (Table $2)$. The importance of ovarian GHRH and/or SRIF in ovarian GH synthesis is uncertain, since GH synthesis in non-pituitary sites is often independent of traditional GH secretagogues (Harvey \& Hull 1997). Moreover, these factors have been shown to have other local roles, unrelated to $\mathrm{GH}$ regulation (Scanes \& Campbell 1995).

GHRs The possibility that ovarian GH may act at local sites is supported by the detection of high-affinity $\left(K_{\mathrm{d}}=2 \cdot 8-6 \cdot 1 \times 10^{-9} \mathrm{M}\right)$ low-capacity binding sites in ovarian membranes (e.g. in rabbits (Ando et al. 1994), swine (Quesnel 1999) and fish (Yao et al. 1991)) and in pig follicles (Quesnel 1999) (Table 3). In fish, this GH- binding activity is preferentially found in intracellular membranes, and, to a lesser extent, in plasma membranes (Yao 1993). GHR mRNA and immunoreactivity are also present in the ovary and other female reproductive tissues of numerous species (Table 1).

GHR gene expression is differentially regulated in ovarian and non-ovarian tissues, suggesting that ovarian GHRs serve an important role in regulating reproductive function. For instance, ovarian and hepatic GHR and GH-binding protein (GHBP) transcripts peak 14 or 20 days post-fertilization respectively (Sakaguchi et al. 1998). A transitory peak in both transcripts is also observed postnatally (day 8), corresponding to the lactation period (Sakaguchi et al. 1998). Intestinal and renal GHR and GHBP transcripts do not follow this pattern (Sakaguchi et al. 1998). GHR transcripts similarly increase in abundance during gestation in cows in the liver and corpora lutea, but not in adipose tissue (Hauser et al. 1990, Yuan \& Lucy 1996b).

Differential regulation of ovarian and non-ovarian GHR transcripts may reflect the use of alternate promoters. For instance an alternate splice variant (1B) has been detected in the bovine ovary and corpora lutea that contains a different promoter from the cloned hepatic GHR mRNA (1A) (Spicer \& Echternkamp 1995, Heap et al. 1996). The $1 \mathrm{~A}$ variant is specific to adult bovine liver but the $1 \mathrm{~B}$ mRNA variant is found in both hepatic and non-hepatic tissues (Lucy et al. 1998). In rats, the $1 \mathrm{~A}$ and $1 \mathrm{~B}$ variants are differentially regulated by $\mathrm{GH}$ and reproductive steroids (Baumbach \& Bingham 1995); thus, GHR synthesis, hence $\mathrm{GH}$ responsiveness, may thus be differentially regulated in hepatic and reproductive tissues (Lucy et al. 1998, Gomez et al. 1999).

IGFs Many of the actions of GH may be induced by the local production of IGFs (Fig. 1, Table 1 and above text), since IGF-I (Geisthoevel et al. 1989) and IGF-I receptors (Poretsky et al. 1985) are usually detectable in ovarian tissues. Moreover, GH increases IGF-I in follicular fluid from humans (Volpe et al. 1992), cows (Sirotkin \& Makarevich 1999), pigs (Sirotkin et al. 1998), and sheep (Juengel et al. 1997) and in perifused rabbit ovaries (Yoshimura et al. 1994). However, circulating GH and ovarian IGF-I are not always related, since GHRH immunization of heifers decreases plasma GH and IGF-I but 
Table 3 GHR/GHBP transcripts and immunoreactivity (IR) and GH-binding sites ${ }^{\dagger}$ in the female reproductive tract

\begin{tabular}{|c|c|c|c|}
\hline & Species & $\begin{array}{l}\text { GHR/GHBP-IR or } \\
\text { GH-binding sites }\end{array}$ & GHR/GHBP mRNA ${ }^{1}$ \\
\hline \multicolumn{4}{|l|}{ Tissue } \\
\hline \multirow[t]{2}{*}{ Ovary } & Rabbit & Ando et al. (1994) & - \\
\hline & Cattle & - & Lucy et al. (1998) \\
\hline \multirow{5}{*}{ Granulosa cells } & Human & Carlsson et al. (1993), Tamura et al. (1994) & Carlsson et al. (1992, 1993), Sharara et al. (1994) \\
\hline & Rat & Lobie et al. (1990) & - \\
\hline & Pigs & ${ }^{\dagger}$ Quesnel (1999) & ${ }^{*}$ Yuan \& Lucy $(1996 b)$ \\
\hline & Cattle & Kolle et al. (1998) & *Yuan \& Lucy (1996b), Izadyar et al. (1997) \\
\hline & Sheep & - & Eckery et al. (1997) \\
\hline \multirow[t]{2}{*}{ Luteinized granulosa cells } & Human & Katz et al. (1993) & - \\
\hline & Cattle & Kolle et al. (1998) & Kolle et al. (1998) \\
\hline \multirow[t]{5}{*}{ Luteal cells } & Human & Carlsson et al. (1993) & Carlsson et al. (1993), Sharara et al. (1994) \\
\hline & Rat & Lobie et al. (1990) & - \\
\hline & Pig & Yuan et al. (1996) & Yuan et al. (1996) \\
\hline & Cattle & Yuan et al. (1996) & $\begin{array}{l}\text { Scott et al. (1992), Lucy et al. (1993a), Yuan \& } \\
\text { Lucy (1996b) }\end{array}$ \\
\hline & Sheep & - & Juengel et al. (1997) \\
\hline \multirow[t]{4}{*}{ Thecal cells } & Human & - & *Katz et al. (1993), *Sharara \& Nieman (1994) \\
\hline & Pig & ${ }^{\dagger}$ Quesnel (1999) & - \\
\hline & Cattle & - & *Kolle et al. (1998) \\
\hline & Rat & Lobie et al. (1990) & - \\
\hline Corpus albicans & Human & - & Sharara et al. (1994) \\
\hline \multirow[t]{5}{*}{ Oocyte } & Human & - & *Sharara et al. (1994) \\
\hline & Rat & Lobie et al. (1990) & - \\
\hline & Pig & ${ }^{\dagger}$ Quesnel (1999) & - \\
\hline & Cattle & Kolle et al. (1998) & Izadyar et al. (1997), Kolle et al. (1998) \\
\hline & Sheep & - & Eckery et al. (1997) \\
\hline Cumulus cells & Cattle & Kolle et al. (1998) & Izadyar et al. (1997), Kolle et al. (1998) \\
\hline Follicular fluid & Human & Amit et al. (1993) & - \\
\hline \multirow[t]{4}{*}{ Uterus } & Human & - & Sharara \& Nieman (1995) \\
\hline & Mouse & - & Sharara et al. (1994) \\
\hline & Rat & Lobie et al. (1990) & - \\
\hline & Cattle & - & $\begin{array}{l}\text { Heap et al. (1996), Kirby et al. (1996), Kolle et al. } \\
\text { (1997) }\end{array}$ \\
\hline \multirow[t]{4}{*}{ Placenta } & Human & $\begin{array}{l}\text { Frankenne et al. (1992), Hill et al. (1992), } \\
\text { Urbanek et al. (1992) }\end{array}$ & - \\
\hline & Rat & Barnard et al. (1994) & Barnard et al. (1994) \\
\hline & Sheep & Lacroix et al. (1999) & - \\
\hline & Cattle & Kolle et al. (1997) & Kolle et al. (1997) \\
\hline \multirow[t]{3}{*}{ Endometrium } & Rat & Lobie et al. (1990) & - \\
\hline & Sheep & Lacroix et al. (1999) & - \\
\hline & Cattle & - & Scott et al. (1992), Kirby et al. (1996) \\
\hline \multirow[t]{2}{*}{ Myometrium } & Rat & Lobie et al. (1990) & - \\
\hline & Cattle & - & Kirby et al. (1996) \\
\hline Amnion & Cattle & - & Scott et al. (1992) \\
\hline Fetal $\mathrm{EEM}^{\ddagger}$ & Cattle & - & Scott et al. (1992) \\
\hline Cotyledon & Cattle & - & Scott et al. (1992) \\
\hline Intercotyledonary membrane & Cattle & - & Scott et al. (1992) \\
\hline Oviduct & Rat & Lobie et al. (1990) & - \\
\hline Mullerian duct & Chickens & tWang (1989) & - \\
\hline \multirow[t]{9}{*}{ Mammary gland } & Human & Mertani et al. (1998) & Mertani et al. (1998) \\
\hline & Human tumour & Mertani et al. (1998) & Mertani et al. (1998) \\
\hline & Rat & Lincoln et al. (1995) & Tiong \& Herington (1991) \\
\hline & Rabbit & Lincoln et al. (1995) & Jammes et al. (1991) \\
\hline & Mouse & - & Ilkbahar et al. (1995) \\
\hline & Fetal Cattle & Knabel et al. (1998) & Knabel et al. (1998) \\
\hline & Cattle & - & Scott et al. (1992), Lucy et al. (1998) \\
\hline & Pig & - & Jammes et al. (1991) \\
\hline & Sheep & - & Jammes et al. (1991) \\
\hline
\end{tabular}

*Not detected. ${ }^{\star}$ Extra-embryonic membrane.

${ }^{1}$ It should be noted that the presence of GHR mRNA is indicative but not proof of function. Similarly, the presence of GHR/GHBP-IR is indicative but not proof of local synthesis and/or function. 
not ovarian IGF-I (Cohick et al. 1996). Indeed, some investigators have failed to detect IGF-I and/or IGF-I mRNA in human granulosa cells (Ovesen et al. 1994) or bovine follicles (El-Roeiy et al. 1993). Ovarian IGF-I in the fish ovary is, moreover, significantly different in sequence from hepatic IGF-I (Kermouni et al. 1998). Basal IGF-I production is similarly at the lower limit of detection in isolated rabbit ovaries (Yoshimura et al. 1994). In vivo $\mathrm{GH}$ administration similarly does not stimulate the synthesis of IGFs or their receptors in pre-menopausal human ovaries (Penarrubia et al. 2000). In addition to its roles in reproduction, the local production of IGF-I in the ovary might provide negative feedback to regulate ovarian GH production, comparable to the regulation of pituitary GH secretion by peripheral IGF-I (Harvey 1995).

\section{Summary}

Components of the hypothalamo-pituitary-hepatic axis for $\mathrm{GH}$ are present in the ovary, including $\mathrm{GH}$, GH secretagogues, GHRs, IGF-I and IGF-I receptors. The ovary may thus contain a GH 'mini-hypophysis', as has been previously described in immune tissues (Hull et al. 1997). This 'mini-hypophysis' may be concerned with short-term ('emergency') modulation of ovarian function in an autocrine or paracrine manner, whereas the traditional ('strategic') hypothalamo-pituitary-target organ axis may regulate more long-term functions, in an endocrine way.

\section{Placental Actions}

\section{Roles of placental GH}

In humans, it is well established that GH modulates maternal metabolism during human pregnancy to induce nutrient repartitioning for fetal development. Pituitary GH deficiency does not, however, abolish the normal pregnancy-induced increase in IGF-I (Eriksson 1989) and does not reduce fetal weight (Curran et al. 1998). Maternal IGF-I abundance is, in contrast, closely correlated with GH of placental origin (Beckers et al. 1990, Caufriez et al. 1993, Mirlesse et al. 1993) and intrauterine growth retardation results from a deficiency in placental GHproducing cells (Mirlesse et al. 1993, Chowen et al. 1996). Conversely, in animals without a placental GH variant, pituitary GH is closely linked with fetal weight. For instance, GH-deficient rats are characterized by low IGF-I, maternal weight gain, and litter size (Gargosky et al. 1993), and GH replacement results in heavier fetuses and faster postnatal growth of pups (Spencer et al. 1994). Litter size and fetal size are also reduced in female GHR-knockout mice, in comparison with normal females (Bartke et al. 1999). Enhanced GH secretion as a result of SRIF immunoneutralization similarly increases the mean birth weight of rat pups (Spencer et al. 1994). Fetal weight in pigs is similarly increased by maternal GH administration (Sterle et al. 1995).

GH may enhance fetal growth by increasing placental size rather than by acting directly on the fetus, since placental GH is not detected in fetal circulation (de Zegher et al. 1990) and maternal GH does not cross the placental barrier (Fholenhag et al. 1994). Indeed, exogenous GH stimulates placental growth in rats (Botero-Ruiz et al. 1997) and pigs (Sterle et al. 1995) and increases the weight of the myoendometrium and gravid uterus in ewes (Jenkinson et al. 1999). The stimulatory effect of GH on placental growth may be mediated at the placenta itself rather than by changes in maternal metabolism, since both pituitary and placental GH have mitogenic activity (Nickel et al. 1990, MacLeod et al. 1991). Moreover, placental GH also stimulates placental IGF-I production (Challier et al. 1991), and enhances endometrial cell growth (Strowitzki et al. 1991).

However, other investigators suggest that GH affects fetal growth independently of placental growth. For instance, Takeda \& Hashimoto (1994) have shown in rats that maternal GH affects placental growth but not fetal growth, and fetal GH affects fetal but not placental growth. Placental GH may also alter the endocrine activity of the placenta, since human $\mathrm{GH}(\mathrm{hGH})$ stimulates production of placental lactogens, oestradiol and progesterone in vitro (Barnea et al. 1989, Di Simone et al. 1995). It also increases DNA synthesis and the growth of fetal tissues in the rat and sheep fetus during the latter part of pregnancy (Botero-Ruiz et al. 1997, Jenkinson et al. 1999).

\section{The placental mini-hypophysis}

The presence of GH or GH-like proteins in the placenta of primates (Alsat et al. 1998), ruminants (Anthony et al. 1995), rodents (Talamantes et al. 1988) and other mammals (Forsyth 1986) is well established. In primates, placental GH-like proteins largely result from expression of the hGH-V gene, which is at least $92 \%$ homologous to the hGH-N gene. GH-V gene expression is largely restricted to the synctiotrophoblast layer of the placenta by proteins that are almost ubiquitous in other tissues and function to repress the hGH-V promoter (Scippo et al. 1993, Alsat et al. 1998). The hGH-V gene may, however, be weakly expressed in normal and tumorous pituitary glands (Scippo et al. 1991, Nickel \& Cattini 1992) and the pituitary GH gene appears to be minimally expressed in human placental tissues (Lacroix et al. 1996).

Placental hGH is the same length (191 amino acids) as pituitary GH but contains 13 different amino acids and is more basic (Frankenne et al. 1988, 1990). Unlike pituitary $\mathrm{GH}$, placental GH contains an N-linked glycosylation site; thus, placental GH isoforms corresponding to nonglycosylated $(22 \mathrm{kDa})$ and glycosylated $(25 \mathrm{kDa})$ proteins are produced (Frankenne et al. 1988, 1990). These small differences are thought to be responsible for the reduced 
lactogenic activity of placental GH compared with pituitary GH (MacLeod et al. 1991). A poorly characterized $\mathrm{GH}-$ like protein is also produced from a splice variant of the hGH-V gene (hGH-V2) and may be membranebound (Cooke et al. 1988). This variant shows complete sequence divergence from hGH in the carboxy terminus. Two other transcripts of the hGH-V gene have also been described; one that predicts a truncated $\mathrm{hGH}-\mathrm{V}$ isoform and one that predicts a novel 219 amino acid protein (hGH-V3) in which the first 124 amino acids are identical to placental GH (Boguszewski et al. 1998).

The GH-V gene is not present in the genomes of non-primates. GH variants are, however, present in the ovine (Lacroix et al. 1996) and rodent (Ogilvie et al. 1990) placentae, and GH mRNA has been detected in the ovine placenta, particularly in trophoectoderm and syncytium (Lacroix et al. 1999).

Placental GHs may act in an endocrine way to regulate extraplacental GH action, since hepatic GHR and GHBP mRNA are more abundant in mice with larger litters (Cramer et al. 1992), presumably because of the higher levels of placental lactogen. Placental GH and/or placental lactogens may also act in a paracrine or autocrine fashion to modulate placental function, since binding activity for placental and pituitary $\mathrm{GH}$ is abundantly present in the human placenta (Ray et al. 1990). The GH-binding activity in the placenta may reside in proteins identical to the cloned hepatic GHR, since GHR/GHBP mRNA and immunoreactivity are abundantly present in trophoblastic cells of the human (Frankenne et al. 1990, Hill et al. 1992, Urbanek et al. 1993), bovine (Kolle et al. 1997), ovine (Lacroix et al. 1999) and rat (Barnard et al. 1994) placenta (Table 3).

In primates, GH-V binds the cloned hepatic GHR with high affinity, and is not completely displaced from placental membranes by hGH-N (Frankenne et al. 1992). A separate, placental hGH-V receptor may thus exist but has yet to be identified. A hGHR gene isoform (hGHRd3), lacking sequences encoded by exon 3 , is also present in the chorion, amnion and decidua of the placenta and is the exclusive isoform in placental villi (Urbanek et al. 1992). The binding characteristics of this isoform are, however, identical to the full-length receptor (Urbanek et al. 1993).

\section{Summary}

In addition to its well-documented effect on maternal metabolism, GH stimulates fetal growth by binding to placental GHRs and increasing placental size. Autocrine and/or paracrine actions of GH may be particularly important in the primate placenta, since the placenta is the primary source of $\mathrm{GH}$ during pregnancy.

\section{Uterine Actions}

Uterine roles of $\mathrm{GH}$

The uterus of pregnant and non-pregnant females is also a site of GH action. For instance, exogenous GH promotes uterine proliferation and cellular growth in rats with (Kennedy \& Doktorcik 1988, Gunin 1997) or without (Miura \& Koida 1970) the addition of oestrogen. Its induction of decidualization in the rat is partly mediated by an upregulation of oestradiol receptors (Chilton \& Daniel 1987, Bezecny et al. 1992) and by an increased production of uterine IGFBPs and prostaglandins (Kennedy \& Doktorcik 1988, Yallampalli et al. 1993). The number of implantation sites is also increased in the uterii of rats transgenically overexpressing the GH gene (Danilovich et al. 2000). In sheep, GH increases the weight of the myoendometrium and the gravid uterus (Jenkinson et al. 1999), probably by stimulating uterine milk protein mRNA levels and stratum spongiosum gland density (Spencer et al. 1999). However, unlike in rats, the uterine effects of GH do not involve the upregulation of oestradiol receptors and may be mediated by interferon tau (Spencer et al. 1999).

The growth promoting actions of $\mathrm{GH}$ in uterine tissues have also been indicated by the very high incidence (81\%) of leiomyomas in women with acromegaly (Cohen et al. 1998) and the prevalence of GHR mRNA in the nuclei and cytoplasm of leiomyomas and myometrial tissue (Sharara \& Nieman 1995). A role for GH in the formation of uterine tumours is also indicated by their suppression in mice in which GH secretion is blocked by neonatal monosodium glutamate treatment (Nagasawa et al. 1985) and their increased incidence in mice with enhanced $\mathrm{GH}$ secretion (Singtripop et al. 1993). The induction of cystic endometrial hyperplasia in dogs may also be mediated by $\mathrm{GH}$, since $\mathrm{GH}$ mRNA and immunoreactive $\mathrm{GH}$ are present in the cytoplasm of glandular epithelial cells (Schoenmakers et al. 1997). The uterus is thus also an extrapituitary site of GH synthesis and action, in which GH may have paracrine or autocrine actions to regulate reproductive function.

\section{Uterine GHRs}

$\mathrm{GH}$-induced changes in uterine growth may be independent of hepatic IGF-I, since GHR mRNA is present throughout the uterine layers of numerous mammalian species (Table 3). For instance, the GHR gene is expressed in the myometrium of non-pregnant humans and mice and in the endometrium, glands and stroma of nonpregnant mice (Sharara et al. 1994, Sharara \& Nieman 1995). A splice variant of the GHR gene has been shown to be preferentially expressed in the bovine endometrium and myometrium (Heap et al. 1996, Lucy et al. 1998). This variant, which is also present in the ovary and corpus luteum, contains an alternative promoter and may permit specific regulation of GHRs involved in reproduction (Heap et al. 1996, Lucy et al. 1998). For instance, hepatic, but not uterine, GHRs are dramatically upregulated at mid-pregnancy in rats (Sakaguchi et al. 1998). Bovine uterine GHR transcripts appear to be more responsive to 
the endocrine changes of pregnancy, since GHR mRNA is not detected in endometrium from non-pregnant cows but is readily detectable in uterine epithelium, glands and blood vessels of pregnant cows, particularly 6 months post-fertilization (Kolle et al. 1997). Conversely, GHR mRNA is detected from day 8 to day 120 in pregnant sheep and day 4 to day 16 in cycling sheep (Lacroix et al. 1999). Species-specific differences in GHR mRNA regulation by gonadal steroids may be responsible for this extensive variation between species, since uterine GHR gene expression is downregulated by GH in cows (Kirby et al. 1996) but unaffected by gonadal steroids in mice (Sharara et al. 1994).

Placental and uterine GHRs may affect reproductive fitness by IGF-I-dependent mechanisms, since IGF-I has been shown to modulate endometrial function (Wang \& Chard 1999). Indeed, IGF-I is present in bovine endometrium and myometrium (Kirby et al. 1996) and IGFBPs are present in the rat and bovine uterus (Yallampalli et al. 1992, Kirby et al. 1996). Uterine IGF-I and IGFBPs are not, however, regulated by GH in rat (Yallampalli et al. 1992) or cows (Kirby et al. 1996); thus, their relevance to uterine $\mathrm{GH}$ function remains uncertain.

\section{Summary}

GH stimulates mitogenesis and, at high levels, tumorigenesis in the uterus. The presence of GH and GHR mRNA in this organ suggests that GH may be acting in a paracrine or autocrine manner.

\section{Oviduct Actions}

The presence of GHR mRNA in the bovine oviduct (Kirby et al. 1996) indicates that it may also be a site of GH action. This is supported by the increased content of cAMP, prostaglandin F- $\alpha$ and IGF-I in cultured bovine epithelial cells incubated with GH (Makarevich \& Sirotkin 1997). The increased shell thickness of eggs laid by GH-treated hens (Donoghue et al. 1990) suggests that the avian oviduct, particularly the shell gland, is a site of $\mathrm{GH}$ action. This possibility is supported by the presence of GHRs and GHR mRNA in these tissues (Hull et al. 1999). Furthermore, the presence of GH proteins in the chicken oviduct (Harvey et al. 1998) suggests that this may reflect an autocrine or paracrine action of $\mathrm{GH}$ produced locally.

\section{Mammary Actions}

\section{Mammogenesis}

GH is obligatory for normal pubertal mammary development. Although pubertal mammary development occurs in response to an increase in oestradiol, it cannot take place in the absence of the pituitary gland or $\mathrm{GH}$ in rats (Kleinberg et al. 1990, Feldman et al. 1993, Walden et al. 1998). Specifically, GH acts on mammary stromal and epithelial tissues in rats to induce the differentiation of ductal epithelia into terminal end buds (TEBs) and alveolar structures and promotes the morphogenesis of the TEBs in the mammary fat pad (Walden et al. 1998). $\mathrm{GH}$ administration to peri-pubertal heifers (Sejrsen et al. 1986, Sandles et al. 1987, Purup et al. 1993) and lambs (McFadden et al. 1990) similarly increases the amount of parenchymal tissue, although overall mammary size may not be increased, and immunization of heifers against GHRH similarly impairs pubertal mammary development (Sejrsen et al. 1999). Increased milk yield resulting from peripubertal GH administration has not, however, been observed in numerous studies in heifers (reviewed by Sejrsen et al. 1999).

The increased mammary growth induced by GH treatment in pregnant heifers (Stelwagen et al. 1991), ewes (Stelwagen et al. 1993) and goats (Knight et al. 1994) is, conversely, accompanied by increased milk yield. The increased mammogenesis appears to reflect hyperplasia during pregnancy, hypertrophy postnatally, and a postponement of mammary differentiation (Sejrsen et al. 1999). However, neither mammary growth nor milk yield is increased by GH treatment in pregnant sows (Farmer et al. 1997).

Expression of the hGH transgene in mice similarly stimulates normal and neoplastic growth of the mammary glands (Bchini et al. 1991, Nasagawa et al. 1993) and GH administration to ageing monkeys increases glandular size and epithelial proliferation of the mammary glands $(\mathrm{Ng}$ et al. 1997). GH also has growth-promoting effects on human mammary cancer cells in vitro (Benlot et al. 1997). The administration of GH does, nevertheless, prevent the age-related involution of the mammary gland that normally occurs in response to increased plasmin activity (Politis et al. 1990).

\section{Galactopoiesis}

$\mathrm{GH}$ is the major galactopoietic hormone in cows and is commonly used to increase milk yield in commercial dairy herds (Tauer \& Knoblauch 1997, Etherton \& Bauman 1998). Indeed, treatment of dairy cows with bGH increases milk yield by $10-40 \%$, by affecting both mammogenesis and lactogenesis (Breier et al. 1991). The importance of $\mathrm{GH}$ in ruminant lactation is further shown by the correlation between $\mathrm{GH}$ gene polymorphisms (Lucy et al. 1993b, Lee et al. 1996, Yao et al. 1996), GHR gene polymorphisms (Falaki et al. 1996), plasma GH levels (Powell \& Keisler 1995) and heritable patterns of GH secretion (Vasilatos \& Wangsness 1981, Klindt 1988, Beerepoot et al. 1991) with milk production. GH treatment also increases milk yield in humans (Milsom et al. 1992) and milk yield and glucose concentration in goats 
(Driancourt \& Disenhaus 1997, Faulkner 1999). Indeed, hGH may provide a useful therapy for lactational insufficiency in mothers of preterm infants (Gunn et al. 1996). $\mathrm{GH}$ resistance and GH deficiency are similarly correlated with impaired lactational performance and consequently offspring survival rate (Barber et al. 1992, Bartke 1999, Bartke et al. 1999).

A variety of metabolic changes have been postulated to account for GH-induced lactation. For instance, GH alters nutrient partitioning to favour mammary gland anabolism and extramammary catabolism (McDowell et al. 1987a,b). Reduced glucose uptake and increased lactate production by skeletal muscles may permit the increased milk yield, milk fat content, milk protein, and lactose observed in GH-treated cows (McDowell et al. 1987a,b). Similarly, $\mathrm{GH}$ or GHRH inhibits lipogenic enzyme synthesis in adipose tissue but stimulates fatty acid synthase gene transcription (but not translation) in mammary gland tissue (Beswick \& Kennelly 1998). Administration of GH antibodies reduces the metabolism of cholesterol and increases microsomal cholesterol and cholesterol ester stores in the rat mammary gland, suggesting roles for GH in mammary fat metabolism and milk production (Shand \& West 1991). In addition, GH may selectively increase nutrient availability in the mammary gland, since GH increases cardiac output and mammary blood flow in cows (Davis et al. 1988, Breier et al. 1991) and goats (Mepham et al. 1984). Galactopoietic effects of GH may also reflect the stimulation of mammogenesis, since ovine $\mathrm{GH}$ treatment of ewes increases milk yield for 8 weeks following the treatment period (Kann et al. 1999).

Early studies hypothesized that systemic IGF-I mediates the effects of $\mathrm{GH}$ on the mammary gland in ruminants, since binding sites for IGF-I, but not GH, are easily detectable in mammary tissue and IGF-I, but not GH, exerts mammogenic effects in vitro (Akers 1985, Shamay et al. 1988, Cohick 1998). In addition, the mitogenic effect of serum relates more closely to the IGF-I concentration than the GH concentration (Sejrsen et al. 1999). An indirect mechanism of $\mathrm{GH}$ action is further supported by the lack of a lactational response to $\mathrm{GH}$ administered s.c. over the bovine mammary gland (Flint \& Knight 1997).

GH may also directly affect mammary function, since GHR mRNA and protein have been detected in the mammary gland of ruminants and other species (Table 3). Experimental studies also suggest a direct effect, since $\mathrm{GH}$ administered through the teat canal in goats results in a small, but significant, increase in milk yield (Collier et al. 1993), although another study observed no change (Sejrsen \& Knight 1994). Moreover, GH implants in the mammary gland of GH-deficient rats stimulates milk production in the treated, but not the contralateral gland (Flint \& Gardner 1994). IGF-I of mammary, rather than hepatic, origin has also been implicated, since milk IGF-I immunoreactivity increases more rapidly than serum
IGF-I immunoreactivity following GH administration in goats (Faulkner 1999). GH thus stimulates mammary IGF-I production more rapidly than hepatic IGF-I production. Accordingly, GH rapidly stimulates IGF-I synthesis in mammary fibroblasts (Mol et al. 1996, Van Garderen et al. 1997) and, synergistically with oestradiol, in the mammary fat pad (Ruan et al. 1995, Walden et al. 1998). GH-induced IGF-I may subsequently affect local function, since IGF-I receptors are present in mammary tissue (Purup et al. 1995, Bassett et al. 1998). Indeed, the galactopoietic response to $\mathrm{GH}$ in goats is correlated with a sustained increase in IGF-I in milk and mammary tissue (Prosser et al. 1991). GH may also facilitate actions of IGF-I on the mammary gland, since the synthesis of plasma IGFBP-3 is increased in GH-treated cows (Davis et al. 1988, Breier et al. 1991).

\section{The mammary mini-hypophysis}

The mammary gland is a site of $\mathrm{GH}$ production as well as action (Mol et al. 1996). GH is found in canine mammary secretions (particularly pre-partum and colostrum) at concentrations 100-1000 times those in plasma; however, milk GH concentrations are not correlated with fetal plasma GH and $\mathrm{GH}$ is not absorbed intact through the canine gastrointestinal tract (Selman et al. 1994, Schoenmakers et al. 1997). The role of 'milk GH' thus remains uncertain, although mammary $\mathrm{GH}$ production results in the recruitment and hyperplasia of stem cells, which differentiate into ductal epithelium by clonal expansion (Mol et al. 1996). Mammary GH also induces maturation of the duct system into TEBs and alveolar structures (Feldman et al. 1993).

Immunoreactive $\mathrm{GH}$ in milk and mammary glands reflects local synthesis more than the sequestering of pituitary $\mathrm{GH}$, since $\mathrm{GH}$ mRNA is readily detectable in normal and neoplastic mammary glands of humans ( $\mathrm{Mol}$ et al. 1995a) and of dogs and cats (Mol et al. 1995b). Mammary GH may also contribute to systemic GH concentrations, since GH immunoreactivity is more abundant in mammary veins than in mammary arteries (Selman et al. 1994). Systemic GH is generally considered to be entirely of pituitary origin, since GH is largely not detected in hypophysectomized animals. However, under particular conditions, mammary GH production noticeably alters systemic GH and could thus exert systemic effects. For instance, progestin-induced mammary GH can induce coat growth and increase serum IGF-I in pituitary GH-deficient German shepherd dogs (Kooistra et al. 1998).

The sequence of mammary GH is identical to its pituitary counterpart, but its secretory and regulatory patterns are significantly different (Mol et al. 1996). For instance, mammary GH secretion is non-pulsatile (Mol et al. 1996) and is not altered by SRIF or GHRH, despite the presence of both peptides in the mammary gland 
(Table 2). This secretory pattern may be characteristic of non-pituitary GH production, since GH secretion from other extrapituitary sites (e.g. placenta) is similarly nonpulsatile and independent of traditional GH secretagogues, although GHRH and SRIF are usually present (Harvey 1995). The chronic, rather than pulsatile, pattern of mammary GH release can heighten tissue responses to $\mathrm{GH}$, since progestin-induced GH production in hypophysectomized and pituitary-deficient dogs can result in acromegalic features despite non-pathophysiological levels of circulating GH (Selman et al. 1994, Kooistra et al. 1998).

$\mathrm{GH}$ regulation in non-pituitary sites usually reflects site-specific influences. For instance, the primary regulator of mammary GH synthesis is likely to be progestins (Loveridge \& Farquhuarson 1993). This possibility is suggested by the symptoms of mammary GH excess that accompany progestin administration in cats and dogs, which include mammary hyperplasia and cellular proliferation (Selman et al. 1994, Mol et al. 1995b, 1996). Indeed, the non-pathological increase in progestins during the luteal phase is sufficient to stimulate mammary $\mathrm{GH}$ production and breast development (Rijnberk \& Mol 1997). The mechanism by which progestins stimulate GH production is still uncertain. Progesterone receptors have been detected on all normal GH-secreting mammary cells, although not on all GH-secreting tumorous mammary cells (Mol et al. 1995a, Van Garderen et al. 1997). Although the sequence of mammary GH cDNAs is identical to pituitary $\mathrm{GH}$ cDNA in both coding and non-coding regions, mammary GH gene expression may be pit-1-independent (Lantinga-van Leeuwen et al. 1999). This possibility is suggested by the low or absent pit-1 gene expression in the mammary glands of dogs with progestin-induced mammary GH excess (Lantinga-van Leeuwen et al. 1999).

GH-binding sites are detectable in bovine mammary glands (Newbold et al. 1997) but are apparently absent from rabbit mammary gland membranes (Zebrowska et al. 1997). It is, nevertheless, well accepted that the mammary gland expresses GHRs and is thus a GH-target site, because GHR mRNA and/or immunoreactivity are readily observable in the mammary glands of numerous species (Table 3). The receptor is present in both mammary epithelium and stromal tissue, although it is much more abundant in the stroma (Ilkbahar et al. 1999). The importance of these receptors in mammary function in rabbits is suggested by the upregulation of GHR gene expression and immunoreactivity during epithelial proliferation and lactation (Jammes et al. 1991, Lincoln et al. 1995). In contrast, expression of both GHR and GHBP mRNA gradually decreases throughout pregnancy in rats and mice and is further reduced during lactation, reaching an overall 7-fold reduction by day 6 of lactation in comparison with mammary tissue of virgin animals (Ilkbahar et al. 1995, Sakaguchi et al. 1998, Ilkbahar et al. 1999).
GHR immunoreactivity and mRNA are also found in the epithelial and stromal cells of the human mammary gland (Mertani et al. 1998). However, unlike rabbits, the level of expression is equivalent in inactive, proliferating, and tumorous mammary glands (Mertani et al. 1998). The sub-cellular distribution of GHR immunoreactivity suggests that both GHRs and GHBPs are synthesized, since the plasma membrane, cytoplasm and nucleus are all immunoreactive (Lincoln et al. 1995). Indeed, GHBPs with similar binding characteristics to serum GHBPs have been detected in milk from numerous mammalian species (Postel-Vinay et al. 1991, Amit et al. 1997). An additional GHBP has been identified in human milk which binds hGH and hPRL with equal affinity, but it is immunologically unrelated to the GHR (Mercado \& Baumann 1994, Amit et al. 1997). The promoter of the bovine mammary GHR transcript differs from that of the well-characterized hepatic transcript (Lucy et al. 1998); thus, mammary and hepatic GH-responsiveness may be differentially regulated.

\section{Summary}

The stimulatory effect of $\mathrm{GH}$ on mammogenesis and lactogenesis has been well established by numerous in vitro and in vivo studies. The involvement of hepatic and local IGF-I in these actions appears to be species-dependent. The mammary gland is also a site of GH synthesis. Mammary GH probably acts locally by autocrine/ paracrine mechanisms but also, at least in dogs, contributes to circulating $\mathrm{GH}$.

\section{Hepatic Actions}

\section{Vitellogenesis}

Many non-mammalian vertebrates (birds, reptiles, amphibia and fish) produce eggs with substantial quantities of yolk. Yolk is deposited into the ovum in the ovary, although the yolk precursors are largely synthesized in the liver. The synthesis of these precursors, vitellogenesis, is primarily controlled by oestradiol, but GH plays an important role. Indeed, in the absence of $\mathrm{GH}$, oestradiolinduced vitellogenesis is severely impaired in hypophysectomized birds (pigeons (Harvey et al. 1978)), reptiles (lizards (Callard et al. 1990), turtles (Ho et al. 1982)) and fish (silver eels (Peyon et al. 1996)) and restored by exogenous $\mathrm{GH}$ administration. The action of oestrogen is dependent upon $\mathrm{GH}$, since $\mathrm{GH}$ induces and/or maintains hepatic oestrogen receptor abundance (Scanes \& Harvey 1995). The interaction of GH with oestradiol in the induction of vitellogenesis is, however, synergistic rather than permissive (Paolucci 1989). In the absence of oestradiol, GH itself can promote vitellogenesis in liver explants or hepatocytes in vitro (Carnevali \& Mosconi 1992, Peyon 
et al. 1996). This may be a physiological role, since pituitary somatotrophs have greater secretory activity during vitellogenesis stages of reproductive activity (Young \& Ball 1983).

\section{Conclusion}

GH has numerous gonadotrophic roles in female reproduction and is additionally progestational, mammogenic and galactopoietic. The actions of $\mathrm{GH}$ are generally progonadal at physiological concentrations and antigonadal at pharmacological concentrations and in pathophysiological excess. These actions are thought to reflect endocrine roles of pituitary $\mathrm{GH}$ and complementary autocrine or paracrine roles of $\mathrm{GH}$ produced within reproductive tissues. The local production of GH within these tissues may thus reflect an 'emergency' mechanism to rapidly regulate or 'fine-tune' cellular functions that are normally regulated in a 'strategic' way by pituitary GH. GH is thus an important regulator of reproduction. However, as the $\mathrm{GH}$ axis is not always required for fertility and as GHresistant patients often have normal pubertal development, it is a modulator of reproduction rather than a bona fide gonadotrophin or primary regulator.

\section{References}

Adashi EY, Resnick CE, D’Ercole AJ, Svoboda ME \& Van Wyk JJ 1985 Insulin-like growth factors as intraovarian regulators of granulosa cell growth and function. Endocrine Reviews 6 400-420.

Adashi EY, Thorner MO \& Jaffe RB 1994 The somatotrophic axis and the reproductive process in health and disease [editorial]. Fertility and Sterility 61 1014-1015.

Advis JP, White SS \& Ojeda SR 1981 Activation of growth hormone short loop negative feedback delays puberty in the female rat. Endocrinology 108 1343-1352.

Akers RM 1985 Lactogenic hormones: binding sites, mammary growth, secretory cell differentiation and milk biosynthesis in ruminants. Journal of Dairy Science 68 501-519.

Alsat E, Guibourdenche J, Luton D, Frankenne F \& Evain-Brion D 1997 Human placental growth hormone. American Journal of Obstetrics and Gynecology 177 1526-1534.

Alsat E, Guibourdenche J, Couturier A \& Evain-Brion D 1998 Physiological role of human placental growth hormone. Molecular and Cellular Endocrinology 140 121-127.

Amit T, Dirnfeld M, Barkey RJ, Peleg I, Hacham H, Abramovici H \& Blumenfeld Z 1993 Growth hormone-binding protein (GH-BP) levels in follicular fluid from human preovulatory follicles correlation with serum GH-BP levels. Journal of Clinical Endocrinology and Metabolism 77 33-39.

Amit T, Dibner C \& Barkey RJ 1997 Characterization of prolactinand growth hormone-binding proteins in milk and their diversity among species. Molecular and Cellular Endocrinology 130 167-180.

Ando M, Yoshimur Y, Iwashita M, Oda T, Karube M, Ubukata Y, Jinno M \& Nakamura Y 1994 Direct ovarian effect of growth hormone in the rabbit. American Journal of Reproductive Immunology 31 123-132.

Andrade LP, Rhind SM, Wright IA, McMillen SR, Goddard PJ \& Bramley TA 1996 Effects of bovine somatotrophin (bST) on ovarian function in post-partum beef cows. Reproduction, Fertility and Development 8 951-960.

Andres CJ, Green ML, Clapper JA, Cline TR \& Diekman MA 1991 Influence of daily injections of porcine somatotropin on growth, puberty, and reproduction in gilts. Journal of Animal Science 69 3754-3761.

Anthony RV, Pratt SL, Liang R \& Holland MD 1995 Placental-fetal hormonal interactions: impact on fetal growth. Journal of Animal Science 73 1861-1871.

Apa R, Lanzone A, Miceli F, Caruso A, Mancuso S \& Canipari R $1994 a$ Growth hormone induction of rat granulosa cell tissue plasminogen activator expression and progesterone synthesis. Molecular and Cellular Endocrinology 99 153-159.

Apa R, Lanzone A, Miceli F, Mastrandrea M, Caruso A, Mancuso S \& Canipari R $1994 b$ Growth hormone induces in vitro maturation of follicle- and cumulus-enclosed rat oocytes. Molecular and Cellular Endocrinology 106 207-212.

Apa R, Caruso A, Andreani G, Miceli F, Lazzarin N, Mastandrea M, Ronsisville E, Mancuso S \& Lanzone A 1996 Growth hormone stimulates androsterone synthesis by rat theca-interstitial cells. Molecular and Cellular Endocrinology 118 95-101.

Bagnato A, Moretti C, Ohno Y, Frajese G \& Catt KJ 1992 Expression of the growth hormone-releasing hormone gene and its peptide product in the rat ovary. Endocrinology $1301097-1102$.

Barber MC, Clegg RA, Finley E, Vernon RG \& Flint DJ 1992 The role of growth hormone, prolactin and insulin-like growth factors in the regulation of rat mammary gland and adipose tissue metabolism during lactation. Journal of Endocrinology 135 195-202.

Barnard R, Thordarson G, Lopez MF, Yamaguchi M, Edens A, Cramer SD, Ogren L \& Talamantes F 1994 Expression of growth hormone-binding protein with a hydrophilic carboxyl terminus by the mouse placenta: studies in vivo and in vitro. Journal of Endocrinology 140 125-135.

Barnea ER, Perlman R, Bick T \& Hochberg Z 1989 Effects of human growth hormone upon term placental hormone secretion in vitro. Gynecologic and Obstetric Investigation 27 133-136.

Barreca A, Artini PG, Delmonte P, Ponzani P, Pasquini P, Cariola G, Volpe A, Genazzani AR, Giordano G \& Minuto F 1993 in vivo and in vitro effect of growth hormone on estradiol secretion by human granulosa cells. Journal of Clinical Endocrinology and Metabolism 77 61-67.

Bartke A 1999 Role of growth hormone and prolactin in the control of reproduction: what are we learning from transgenic and knockout animals? Steroids 64 598-604.

Bartke A, Chandrashekar V, Turyn D, Steger RW, Debeljuk L, Winters TA, Mattison JA, Danilovich N, Croson W, Wernsing DR \& Kopchick J 1999 Effects of growth hormone overexpression and growth hormone resistance on neuroendocrine and reproductive functions in trangenic and knock-out mice. Proceedings of the Society for Experimental Biology and Medicine 222 113-123.

Bassett NS, Currie MJ, Breier BH, Klempt M, Min SH, McCutcheon SN, MacKenzie DDS \& Gluckman PD 1998 The effects of ovine placental lactogen and bovine growth hormone on hepatic and mammary gene expression in lactating sheep. Growth Regulation $\mathbf{8}$ 439-446.

Baumbach WR \& Bingham B 1995 One class of growth hormone $(\mathrm{GH})$ receptor and binding protein messenger ribonucleic acid in rat liver, GHR1, is sexually dimorphic and regulated by GH. Endocrinology 136 749-760.

Baumeister H, Kreuzer OJ, Roosterman D, Schafer J \& Meyerhof W 1998 Cloning, expression, pharmacology and tissue distribution of the mouse somatostatin receptor subtype 5. Journal of Neuroendocrinology 10 283-290.

Bchini O, Andres AC, Schubaur B, Mehtali M, LeMeur M, Lathe R \& Gerlinger P 1991 Precocious mammary gland development and milk protein synthesis in transgenic mice ubiquitously expressing human growth hormone. Endocrinology 128 539-546.

Beckers A, Stevenaert A, Foidart JM, Hennen G \& Frankenne F 1990 Placental and pituitary growth hormone secretion during pregnancy in acromegalic women. Journal of Clinical Endocrinology and Metabolism 71 725-731. 
Beerepoot GM, Freeman AE \& Detilleux JC 1991 Effect of season, genetic line, and sire on growth concentrations of somatotropin in serum of Holstein cows in early lactation. Journal of Dairy Science $\mathbf{7 4}$ 3202-3208.

Benlot C, Levy L, Fontanaud P, Roche A, Rouannet P \& Joubert D 1997 Somatostatin and growth hormone-releasing hormone in normal and tumoral human breast tissue: endogenous content, in vitro pulsatile release, and regulation. Journal of Clinical Endocrinology and Metabolism 82 690-696.

Bergh C, Hillensjo T, Wikland M, Nilsson L, Borg G \& Hanberger L 1994 Adjuvant growth hormone treatment during in vitro fertilization: a randomized placebo-controlled study. Fertility and Sterility 62 113-120.

Berry SA, Srivastava CH, Rubin LR, Phipps WR \& Pescovitz OH 1992 Growth hormone-releasing hormone-like messenger ribonucleic acid and immunoreactive peptide are present in human testis and placenta. Journal of Clinical Endocrinology and Metabolism 75 281-284.

Beswick NS \& Kennelly JJ 1998 The influence of bovine growth hormone and growth hormone releasing factor on acetyl-CoA carboxylase and fatty acid synthase in primiparous Holstein cows. Comparative Biochemistry and Pharmacology 120 241-249.

Bevers MM, Van Tol HT \& de Loos FAM 1989 Protein patterns in immature bovine oocytes incubated with ${ }^{35} \mathrm{~S}$-methionine in either medium or medium with dibutyryl cyclic AMP or follicular fluid. Proceedings of the 12th International Congress of Animal Reproduction, The Hague $1312-314$ (Abstract).

Bezecny I, Bartova J \& Skarda J 1992 Growth hormone treatment increases oestrogen receptor concentration in the guinea-pig uterus. Journal of Endocrinology 134 5-9.

Blumenfeld Z \& Amit T 1993 Role of GH in ovulation induction. In Basic and Clinical Advances in Pituitary Disease, pp 205-208. Ed. S Melmed. Los Angeles: Endocrine Research and Teaching.

Blumenfeld Z \& Lunenfeld B 1989 The potentiating effect of growth hormone on follicle stimulation with human menopausal gonadotropin. Fertility and Sterility 52 328-331.

Blumenfeld Z, Amit T, Barkley RJ, Lunenfeld B \& Brandes JM 1991 Synergistic effect of growth hormone in achieving conception in 'clonidine negative' patients with unexplained fertility. Annals of the New York Academy of Sciences 626 250-265.

Blumenfeld Z, Barkey RJ, Youdim MBH, Brandes JM \& Amit T 1992 Growth hormone (GH)-binding protein regulation by estrogen, progesterone, and gonadotropins in human: the effect of ovulation induction with menopausal gonadotropins, GH, and gestation. Journal of Clinical Endocrinology and Metabolism $\mathbf{7 5}$ 1242-1249.

de Boer JA, Schoemaker J \& Van der Veen EA 1997 Impaired reproductive function in women treated for growth hormone deficiency during childhood. Clinical Endocrinology 46 681-689.

Boguszewski CL, Svensson P, Jansson T, Clark R, Carlsson LM \& Carlsson B 1998 Cloning of two novel growth hormone transcripts expressed in human placenta. Journal of Clinical Endocrinology and Metabolism 83 2878-2885.

Botero-Ruiz W, Biggers WJ \& Sanyal MK 1997 Augmentation of DNA synthesis in placental and fetal tissues in utero by maternal growth hormone treatment. Early Pregnancy: Biology and Medicine 3 272-280.

Breier BH, Gluckman PD, McCutcheon SN \& Davis SR 1991 Physiological responses to sumatotropin in the ruminant. Journal of Dairy Science 74 (Suppl 2) 20-34.

Bryan KA, Hammond AC, Canning SF, Mondshein JS, Carel JC, Clark AM \& Hagen DR 1989 Reproductive and growth responses of gilts to exogenous porcine pituitary growth hormone. Journal of Animal Science 67 195-205.

Bryan KA, Clark AJ \& Hagen DR 1990 Effect of treatment with and subsequent withdrawal of exogenous porcine somatotropin on growth and reproductive characteristics of gilts. Journal of Animal Science 68 2357-2361.
Bryan KA, Hagen DR \& Hammond JM 1992 Effect of frequency of administration of exogenous porcine growth hormone on growth and carcass traits and ovarian function of prepubertal gilts. Journal of Animal Science 70 1454-1463.

Burger HG, Kovacs GT, Polson DM, McDonald J, McCloud PI, Harrop M, Colman P \& Healy DL 1991 Ovarian sensitization to gonadotropins by human growth hormone. Persistence of the effect beyond the treated cycle. Clinical Endocrinology 35 119-122.

Callard IP, Riley D \& Perez L 1990 Vitellogenesis in reptiles as a model for mammalian sex-differentiated hepatic protein synthesis. Journal of Experimental Zoology Supplement 4 106-111.

Carlsson B, Bergh C, Bentham J, Olsson JH, Norman MR, Billig H, Roos P \& Hillensjo T 1992 Expression of functional growth hormone receptors in human granulosa cells. Human Reproduction 7 1205-1209.

Carlsson B, Nilsson A, Isaksson OGP \& Billig H 1993 Growth hormone-receptor messenger RNA in the rat ovary-regulation and localization. Molecular and Cellular Endocrinology 95 59-66.

Carnevali O \& Mosconi G 1992 in vitro induction of vitellogenin synthesis in Rana esculenta - role of the pituitary. General and Comparative Endocrinology 86 352-358.

Caron P, Buscail L, Beckers A, Esteve JP, Igout A, Hennen G \& Susini C 1997 Expression of the somatostatin receptor SST4 in human placenta and absence of octreotide effect on human placental growth hormone concentration during pregnancy. Journal of Clinical Endocrinology and Metabolism 82 3771C-3776C.

Caufriez A, Frankenne F, Hennen G \& Copinschi G 1993 Regulation of maternal IGF-I by placental GH in normal and abnormal human pregnancies. American Journal of Physiology 265 E572-E577.

Cecim M, Kerr J \& Bartke A 1995 Effects of bovine growth hormone (bGH) transgene expression or bGH treatment on reproductive functions in female mice. Biology of Reproduction 52 1144-1148.

Cento RM, Ragusa L, Proto C, Alberti A, Fiore G, Colabucci F \& Lanzone A 1997 Ovarian sensitivity to follicle stimulating hormone is blunted in normo-ovulatory women with Down's syndrome. Human Reproduction 12 1709-1713.

Challier JC, Frankenne F, Bintein T, Poncelet M \& Hennen G 1991 Release of placental GH by perfused human placenta. Placenta 12 377-378.

Chase CC, Kirby CJ, Hammond AC, Olson TA \& Lucy MC 1998 Patterns of ovarian growth and development in cattle with a growth hormone receptor deficiency. Journal of Animal Science 76 212-219.

Chilton BS \& Daniel JC 1987 Differences in the rabbit uterine response to progesterone as influenced by growth hormone or prolactin. Journal of Reproduction and Fertility 79 581-587.

Chowen JA, Evain-Brion D, Pozo J, Alsat E, Garcia-Segura LM \& Argente J 1996 Decreased expression of placental growth hormone in intrauterine growth retardation. Pediatric Research 39 736-739.

Cochran RA, Leonardi-Cattolica AA, Sullivan MR, Kincaid LA, Leise BS, Thompson DL \& Godke RA 1999 The effects of equine somatotropin (eST) on follicular development and circulating plasma hormone profiles in cyclic mares treated during different stages of the estrous cycle. Domestic Animal Endocrinology 16 57-67.

Cohen O, Schindel B \& Homburg R 1998 Uterine leiomyomata - a feature of acromegaly. Human Reproduction 13 1945-1946.

Cohick WS 1998 Role of the insulin-like growth factors and their binding proteins in lactation. Journal of Dairy Science 81 1769-1777.

Cohick WS, Armstrong JD, Whitacre MD, Lucy MC, Harvey RW \& Campbell RM 1996 Ovarian expression of insulin-like growth factor-I (IGF-I), IGF binding proteins, and growth hormone (GH) receptor in heifers actively immunized against GH-releasing factor. Endocrinology 137 1670-1677.

Collier RJ, McGrath MF, Byatt JC \& Zurfluh LL 1993 Regulation of bovine mammary growth by peptide hormones: involvement of receptors, growth factors and binding proteins. Livestock Production Science 35 21-34.

Cooke NE, Ray J, Watson MA, Estes PA, Kuo BA \& Liebhauber SA 1988 Two distinct species of human growth hormone variant 
mRNA in the human placenta predict the expression of novel growth hormone proteins. Journal of Biological Chemistry 263 9001-9006.

Cramer SD, Wong L, Kensinger RS, Ogren L \& Talamantes F 1992 Regulation of the hepatic growth hormone receptor and serum growth hormone-binding protein during pregnancy in the mouse: effects of litter size. Endocrinology 131 2914-2920.

Curran AJ, Peacey SR \& Shalet SM 1998 Is maternal growth hormone essential for a normal pregnancy? European Journal of Endocrinology 139 54-58.

Danilovich N, Wernsing D, Coschigano KT, Kopchick J \& Bartke A 1999 Deficits in female reproductive function in GH-R-KO mice: role of IGF-I. Endocrinology 140 2637-2640.

Danilovich N, Bartke A \& Winters TA 2000 Ovarian follicle apoptosis in bovine growth hormone transgenic mice. Biology of Reproduction 62 103-107.

Darendeliler F, Hindmarsh PC, Preece MA, Cox L \& Brook CGD 1990 Growth hormone increases rate of pubertal maturation. Acta Endocrinologica 122 414-416.

Davis SR, Collier RJ, McNamara JP, Head HH, Croom WJ \& Wilcox CJ 1988 Effects of thyroxine and growth hormone treatment of dairy cows on mammary uptake of glucose, oxygen and other milk fat precursors. Journal of Animal Science 66 80-89.

Davis SR, Smith JF \& Gluckman PD 1990 Effects of growth hormone injections on ovulation rate in ewes. Reproduction, Fertility and Development 2 173-178.

Decuypere E, Huybrechts LM, Kuhn ER, Tixier-Boichard M \& Merat P 1991 Physiological alterations associated with the chicken sex-linked dwarfing gene. Critical Reviews in Poultry Biology 2 191-221.

DeLaSota RL, Lucy MC, Staples CR \& Thatcher WW 1993 Effects of recombinant bovine somatotropin on ovarian function in lactating and nonlactating dairy cows. Journal of Dairy Science $\mathbf{7 6}$ 1002-1013.

Di Simone N, Caruso A, Lanzone A, Piccirillo G, Castellani R, Ronsisvalle E, Giannice R \& Mancuso S 1995 In vitro human growth hormone increases human chorionic gonadotropin and progesterone secretion by human placenta at term: evidence of a modulatory role by opioids. Gynecological Endocrinology 9 157-164.

Doldi N, Bassan M, Bonzi V \& Ferrari A 1996 Effects of growth hormone and growth hormone-releasing hormone on steroid synthesis in cultured human luteinizing granulosa cells. Gynecological Endocrinology 10 101-108.

Donoghue DJ, Campbell RM \& Scanes CG 1990 Effect of biosynthetic chicken growth hormone on egg production in White Leghorn hens. Poultry Science 69 1818-1821.

Dor J, Ben-Shlomo I \& Lunenfeld B 1992 Insulin-like growth factor-I (IGF-I) may not be essential for ovarian follicular development: evidence from IGF-I deficiency. Journal of Clinical Endocrinology and Metabolism 74 539-542.

Driancourt MA \& Disenhaus C 1997 Lack of effects of growth hormone administration on ovarian function of lactating goats. Animal Reproduction Science 46 123-132.

Eckery DC, Moeller CL, Nett TM \& Sawyer HR 1997 Localization and quantification of binding sites for follicle-stimulating hormone, luteinizing hormone, growth hormone, and insulin-like growth factor I in sheep ovarian follicles. Biology of Reproduction $\mathbf{5 7}$ 507-513.

Eisenhauer KM, Chun SY, Billig H \& Hsueh AJ 1995 Growth hormone suppression of apoptosis in preovulatory rat follicles and partial neutralization by insulin-like growth factor binding protein. Biology of Reproduction 53 13-20.

El-Roeiy A, Chen X \& Roberts VJ 1993 Expression of insulin-like growth factor (IGF-I) and IGF-II and the IGF-I, IGF-II, and insulin receptor genes and localization of the gene products in the human ovary. Journal of Clinical Endocrinology and Metabolism 77 1411-1418.
Eriksson L 1989 Growth hormone in human pregnancy. Acta Obstetrica et Gynecologica Scandinavica 147 3-38.

Etherton TD \& Bauman DE 1998 Biology of somatotropin in growth and lactation of domestic animals. Physiological Reviews 78 745-761.

Falaki M, Gengler N, Sneyers M, Prandi A, Massart S, Formigoni A, Burny A, Portetelle D \& Renaville R 1996 Relationships of polymorphisms for growth hormone and growth hormone receptor genes with milk production traits for Italian Holstein-Friesian bulls. Journal of Dairy Science 79 1446-1453.

Farmer C, Pelletier G, Brazeau P \& Petitclerc D 1997 Mammary gland development of sows injected with growth hormone-releasing factor during gestation and/or lactation. Canadian Journal of Animal Science 77 335-338.

Faulkner A 1999 Changes in plasma and milk concentrations of glucose and IGF-I in response to exogenous growth hormone in lactating goats. Journal of Dairy Research 66 207-214.

Feldman M, Ruan W, Cunningham BC, Wells JA \& Kleinberg DL 1993 Evidence that the growth hormone receptor mediates differentiation and development of the mammary gland. Endocrinology 133 1602-1608.

Fholenhag KI, Sandstrom IM, Malmof K, Skottner AI \& Nyberg FJ 1994 Human growth hormone does not cross the placenta of the pregnant rat. Growth Regulation 4 181-187.

Flint DJ \& Gardner M 1994 Evidence that growth hormone stimulates milk synthesis by direct action on the mammary gland and that prolactin exerts effects on milk secretion by maintenance of mammary deoxyribonucleic acid content and tight junction status. Endocrinology 135 1119-1124.

Flint DJ \& Knight CH 1997 Interactions of prolactin and growth hormone $(\mathrm{GH})$ in the regulation of mammary gland function and epithelial cell survival. Journal of Mammary Gland Biology and Neoplasia 2 41-48.

Forsyth IA 1986 Variation among species in the endocrine control of mammary growth and function: the roles of prolactin, growth hormone, and placental lactogen. Journal of Dairy Science 69 886-903.

Fowler PA \& Templeton A 1991 Commentary. Ovarian response to gonadotrophins: effects of growth hormone. Clinical Endocrinology 35 $117-118$

Frankenne F, Closset J, Gomez F, Scippo ML, Smal J \& Hennen G 1988 The physiology of growth hormones (GHs) in pregnant women and partial characterization of the placental GH variant Journal of Clinical Endocrinology and Metabolism 66 1171-1180.

Frankenne F, Scippo ML, Beeuman JV, Igout A \& Hennen G 1990 Identification of placental human growth hormone as the growth hormone-V gene expression product. Journal of Clinical Endocrinology and Metabolism 71 15-18.

Frankenne F, Alsat E, Scippo ML, Igout A, Hennen G \& Evain-Brion D 1992 Evidence for the expression of growth hormone receptors in human placenta. Biochemical and Biophysical Research Communications 182 481-486.

Franks S 1998 Growth hormone and ovarian function. Baillieres Clinical Endocrinology and Metabolism 12 331-340.

Gallo GF \& Block E 1991 Effects of recombinant bovine somatotropin on hypophyseal and ovarian functions of lactating dairy cows. Canadian Journal of Animal Science 71 343-353.

Gargosky SE, Nantosalonen K, Tapanainen P \& Rosenfeld RG 1993 Pregnancy in growth Hormone-deficient rats - assessment of insulin-like growth factors (IGFs), IGF-binding proteins (IGFBPs) and IGFBP protease activity. Journal of Endocrinology 136 479-489.

Geisthoevel F, Moretti Rojas IM, Rojas FJ \& Asch RH 1989 Immunoreactive insulin-like growth factor in human follicular fluid. Human Reproduction 4 35-38.

Gilbertson J, Kirkwood RN \& Thacker PA 1991 Timing of growth hormone injections and reproduction in gilts. Canadian Journal of Animal Science 71 717-723.

Gomez JM, Loir M \& Le Gac F 1998 Growth hormone receptors in testis and liver during the spermatogenetic cycle in rainbow trout (Oncorhynchus mykiss). Biology of Reproduction 58 483-491. 
Gomez JM, Mourot B, Fostier A \& Le Gac F 1999 Growth hormone receptors in ovary and liver during gametogenesis in female rainbow trout (Oncorhynchus mykiss). Journal of Reproduction and Fertility 115 275-285.

Gong JG, Bramley TA \& Webb R 1991 The effect of recombinant bovine somatotropin on ovarian function in heifers: follicular populations and peripheral hormones. Biology of Reproduction 45 941-949.

Gong JG, McBride D, Bramley TA \& Webb R 1993 Effects of recombinant bovine somatotropin, insulin-like growth factor-I and insulin on the proliferation of bovine granulosa cells in vitro. Journal of Endocrinology 139 67-75.

Gunin AG 1997 Influence of growth hormone on the uterine response to oestradiol in rats. Journal of Reproduction and Fertility $\mathbf{1 1 0}$ 299-306.

Gunn AJ, Gunn TR, Rabone DL, Breier BH, Blum WF \& Gluckman PD 1996 Growth hormone increases breast milk volumes in mothers of preterm infants. Pediatrics 98 279-282.

Hagen DR \& Graboski RA 1990 Effects of porcine pituitary growth hormone $(\mathrm{pGH})$ on cytoplasmic maturation of porcine oocytes in vitro. Journal of Animal Science 68446.

Harvey S 1995 Growth hormone release: feedback control. In Growth Hormone, pp 163-185. Eds S Harvey, CG Scanes \& WR Daughaday. Boca Raton: CRC Press.

Harvey S \& Hull KL 1997 Growth hormone: a paracrine growth factor? Endocrine 7 267-279.

Harvey S, Scanes CG, Chadwick A, Knight PJ \& Callard IP 1978 Effect of growth hormone and oestradiol on vitellogenesis in hypophysectomized pigeons. IRCS Journal of Medical Science 6198.

Harvey S, Sharma P, Johnson CDM, Sanders EJ \& Hull KL 1998 Growth hormone: an embryonic growth factor? Comparative Biochemistry and Pharmacology 119 305-315.

Hauser SD, McGrath MF, Collier RJ \& Krivi GG 1990 Cloning and in vivo expression of bovine growth hormone receptor mRNA. Molecular and Cellular Endocrinology 72 187-200.

Heap D, Collier RJ, Boyd CK \& Lucy MC 1996 Expression of alternate growth hormone receptor messenger RNA in ovary and uterus of cattle. Domestic Animal Endocrinology 13 421-430.

Hill DJ, Riley SC, Bassett NS \& Waters MJ 1992 Localization of the growth hormone receptor, identified by immunocytochemistry, in second trimester human fetal tissues and in placenta throughout gestation. Journal of Clinical Endocrinology and Metabolism $\mathbf{7 5}$ 646-650.

Hillensjo T \& Bergh C 1993 Effects of growth hormone on reproduction. Acta Endocrinologica 128 (Suppl 2) 23-25.

Ho SM, Taylor S \& Callard IP 1982 Effect of hypophysectomy and growth hormone on estrogen-induced vitellogenesis in the freshwater turtle, Chrysemys picta. General and Comparative Endocrinology 48 254-260.

Homburg R \& Farhi J 1995 Growth hormone and reproduction. Current Opinion in Obstetrics and Gynecology 7 220-223.

Homburg R, West C, Toressani T \& Jacobs HS 1990 Cotreatment with human growth hormone and gonadotropins for induction of ovulation: a controlled clinical trial. Fertility and Sterility $\mathbf{5 3}$ 254-260.

Homburg R, West C, Ostergaard H \& Jacobs HS 1991 Combined growth hormone and gonadotrophin treatment for ovulation induction in patients with non-responsive ovaries. Gynecological Endocrinology 5 33-36.

Hong H \& Herington AC 1991 Differentiation between the effects of IGF-I and GH on PMSG-induced progesterone production by rat granulosa cells. Growth Regulation 1 65-71.

Hsu CJ \& Hammond JM 1987 Concomitant effects of growth hormone on secretion of insulin-like growth factor I and progesterone by cultured porcine granulosa cells. Endocrinology 121 1343-1348.

Hughes SM, Huang ZH, Morris ID, Matson PL, Buck P \& Liberman BA 1994 A double-blind cross-over controlled study to evaluate the effect of human biosynthetic growth hormone on ovarian stimulation in previous poor responders to in vitro fertilization. Human Reproduction 9 13-18.

Hull KL, Janssens WC \& Harvey S 1997 Growth hormone: actions in sites of synthesis. In Perspectives in Avian Endocrinology, pp 375-387. Eds S Harvey \& RJ Etches. Bristol: Journal of Endocrinology Ltd.

Hull KL, Murphy A, Luna M, Arambura C \& Harvey S 1999 Growth hormone: a reproductive paracrine/endocrine? Fifth International Congress of Comparative Physiology and Biochemistry, Calgary, Alberta, August 1999 (Abstract).

Hutchinson LA, Findley JK \& Herington AC 1988 Growth hormone and insulin-like growth factor accelerate PMSG-induced differentiation of granulosa cells. Molecular and Cellular Endocrinology 55 61-69.

Hyttel P, Greve T \& Callesen H 1989 Ultrastructural aspects of oocyte maturation and fertilization in cattle. Journal of Reproduction and Fertility Supplement 38 35-47.

Ibrahim ZHZ, Matson PL, Buck P \& Lierberman BA 1991 The use of biosynthetic growth hormone to augment ovulation induction with buserelin acetate/human menopausal gonadotropin in women with a poor ovarian response. Fertility and Sterility 55 202-204.

Ilkbahar YN, Wu K, Thordarson G \& Talamantes F 1995 Expression and distribution of messenger ribonucleic acids for growth hormone $(\mathrm{GH})$ receptor and $\mathrm{GH}$-binding protein in mice during pregnancy. Endocrinology 136 386-392.

Ilkbahar YN, Thordarson G, Camarillo IG \& Talamantes F 1999 Differential expression of the growth hormone receptor and growth hormone binding protein in epithelia and stroma of the mouse mammary gland at various physiological stages. Journal of Endocrinology 161 77-87.

Ilondo MM, Vanderschueren-Lodeweyckx M, Vlietnick R, Pizarro M, Malvaux P, Eggermont E \& Eeckels R 1982 Plasma androgens in children and adolescents. Part II. A longitudinal study in patients with hypopituitarism. Hormone Research 16 78-95.

Izadyar F, Colenbrander B \& Bevers MM 1996 In vitro maturation of bovine oocytes in the presence of growth hormone accelerates nuclear maturation and promotes subsequent embryonic development. Molecular Reproduction and Development 45 372-377.

Izadyar F, Colenbrander B \& Bevers MM 1997 Stimulatory effect of growth hormone on in vitro maturation of bovine oocytes is exerted through the cyclic adenosine $3^{\prime}, 5^{\prime}$-monophosphate signaling pathway. Biology of Reproduction 57 1484-1489.

Izadyar F, Hage WJ, Colenbrander B \& Bevers MM 1998 The promotory effect of growth hormone on the developmental competence of in vitro matured bovine oocytes is due to improved cytoplasmic maturation. Molecular Reproduction and Development 49 444-453.

Jacobs HS 1992 Growth hormone and ovulation - is there an indication for treatment of infertile women with growth hormone. Hormone Research 38 14-21.

Jammes H, Gaye P, Belair L \& Djiane J 1991 Identification and characterization of growth hormone receptor mRNA in the mammary gland. Molecular and Cellular Endocrinology 75 27-35.

Jenkinson CM, Min SH, Mackenzie DD, McCutcheon SN, Breier BH \& Gluckman PD 1999 Placental development and fetal growth in growth hormone-treated ewes. Growth Hormone and IGF Research 9 11-17.

Jia XC, Kalmijn J \& Hsueh AJ 1986 Growth hormone enhances follicle-stimulating hormone-induced differentiation of cultured rat granulosa cells. Endocrinology 118 1401-1409.

Juengel JL, Meberg BM, Turzillo AM, Nett TM \& Niswender GD 1995 Hormonal regulation of messenger ribonucleic acid encoding steroidogenic acute regulatory protein (StAR) by insulin-like growth factor I: synergism with follicle-stimulating hormone or protein kinase A agonist. Endocrinology 136 5423-5429.

Juengel JL, Nett TM, Anthony RV \& Niswender GD 1997 Effects of luteotrophic and luteolytic hormones on expression of mRNA 
encoding insulin-like growth factor I and growth hormone receptor in the ovine corpus luteum. Journal of Reproduction and Fertility 110 291-298.

Kalous J, Nagyova E, Sutovsky P, King WA \& Motlik J 1998 Effects of follicle-stimulating hormone, bovine somatotrophin and okadaic acid on cumulus expansion and nuclear maturation of blue fox oocytes in vitro. Zygote 6 299-309.

Kann G, Delobelle-Deroide A, Belair L, Gertler A \& Djiane J 1999 Demonstration of in vivo mammogenic and lactogenic effects of recombinant ovine placental lactogen and mammogenic effect of recombinant ovine $\mathrm{GH}$ in ewes during artificial induction of lactation. Journal of Endocrinology 160 365-377.

Katz E, Ricciarelli E \& Adashi EY 1993 The potential relevance of growth hormone to female reproductive physiology and pathophysiology. Fertility and Sterility 59 8-34.

Kennedy TG \& Doktorcik PE 1988 Uterine decidualization in hypophysectomized-ovariectomized rats: effects of pituitary hormones. Biology of Reproduction 39 318-328.

Kermouni A, Mahmoud SS, Wang S, Moloney M \& Habibi HR 1998 Cloning of a full-length insulin-like growth factor-I complementary DNA in the goldfish liver and ovary and development of a quantitative PCR method for its measurement. General and Comparative Endocrinology 111 51-60.

Kirby CJ, Thatcher WW, Collier RJ, Simmen FA \& Lucy MC 1996 Effects of growth hormone and pregnancy on expression of growth hormone receptor, insulin-like growth factor-I, and insulin-like growth factor binding protein-2 and -3 genes in bovine uterus, ovary, and oviduct. Biology of Reproduction $\mathbf{5 5}$ 996-1002.

Kleinberg DL, Ruan W, Catanese V, Newman CB \& Feldman M 1990 Non-lactogenic effects of growth hormone on growth and insulin-like growth factor-I messenger ribonucleic acid of rat mammary gland. Endocrinology 126 3274-3276.

Klindt J 1988 Relationships among growth hormone and prolactin secretory parameter estimates in Holstein bulls and their predicted differences for lactational traits. Journal of Animal Science $\mathbf{6 6}$ 2784-2790

Knabel M, Kolle S \& Sinowatz F 1998 Expression of growth hormone receptor in the bovine mammary gland during prenatal development. Anatomy and Embryology 198 163-169.

Knight CH, Brown JR \& Sejrsen K 1994 A comparison of growth hormone-induced mammogenesis in pregnant and lactating goats. Endocrinology and Metabolism 1 (Suppl B) 52.

Kobayashi J, Mizunuma H, Kikuchi N, Liu X, Andoh K, Abe Y, Yokota H, Yamada K, Ibuki Y \& Hagiwara H 2000 Morphological assessment of the effect of growth hormone on preantral follicles from 11-day-old mice in an in vitro culture system. Biochemical and Biophysical Research Communications 268 36-41.

Kolle S, Sinowatz F, Boie G, Lincoln D \& Waters MJ 1997 Differential expression of the growth hormone receptor and its transcript in bovine uterus and placenta. Molecular and Cellular Endocrinology 131 127-136.

Kolle S, Sinowatz F, Boie G \& Lincoln D 1998 Developmental changes in the expression of the growth hormone receptor messenger ribonucleic acid and protein in the bovine ovary. Biology of Reproduction 59 836-842.

Kooistra HS, Voorhout G, Selman PJ \& Rijnberk A 1998 Progestininduced growth hormone $(\mathrm{GH})$ production in the treatment of dogs with congenital GH deficiency. Domestic Animal Endocrinology 15 93-102.

Kumar TR, Wang Y, Lu N \& Matzuk MM 1997 Follicle stimulating hormone is required for ovarian follicle maturation but not male fertility. Nature Genetics 15 201-204.

Lacroix MC, Jammes H \& Kann G 1996 Occurrence of a growth hormone-releasing hormone-like messenger ribonucleic acid and immunoreactive peptide in the sheep placenta. Reproduction, Fertility and Development 8 449-456.
Lacroix MC, Devinoy E, Cassy S, Servely J, Vidaud M \& Kann G 1999 Expression of growth hormone and its receptor in the placental and feto-maternal environment during early pregnancy in sheep. Endocrinology 140 5587-5597.

Langhout DJ, Spicer LJ \& Geisert RD 1991 Development of a culture system for bovine granulosa cells: effects of growth hormone, estradiol, and gonadotropins on cell proliferation, steroidogenesis and protein synthesis. Journal of Animal Science 69 3321-3334.

Lantinga-van Leeuwen IS, Oudshoorn M \& Mol JA 1999 Canine mammary growth hormone gene transcription initiates at the pituitary-specific start site in the absence of Pit-1. Molecular and Cellular Endocrinology 150 121-128.

Lanzone A, Di Simone N, Castellani R, Fulghesu AM, Caruso A \& Mancuso S 1992 Human growth hormone enhances progesterone production by human luteal cells in vitro: evidence of a synergistic effect with human chorionic gonadotropin. Fertility and Sterility $\mathbf{5 7}$ 92-96.

Laron Z 1984 Laron-type dwarfism (hereditary somatomedin deficiency): a review. Ergebnisse der Inneren Medizin und Kinderheilkunde 51 117-150.

Lee BK, Lin GF, Crooker BA, Murtaugh MP, Hansen LB \& Chester-Jones H 1996 Association of somatotropin (BST) gene polymorphism at the 5th exon with selection for milk yield in Holstein cows. Domestic Animal Endocrinology 13 373-381.

Lee JN, Wu P \& Chard T 1982 Identification of somatostatin in the human placenta. Acta Endocrinologica 99 601-604.

Liebermann J \& Schams D 1994 Actions of somatotropin on oxytocin and progesterone release from the microdialysed bovine corpus luteum in vitro. Journal of Endocrinology 143 243-250.

Lincoln DT, Sinowatz F, el-Hifnawi E, Hughes RL \& Waters M 1995 Evidence of a direct role for growth hormone (GH) in mammary gland proliferation and lactation. Anatomy, Histology and Embryology 24 107-115.

Liu X, Andoh K, Yokota H, Kobayashi J, Abe Y, Yamada K, Mizunuma H \& Ibuki Y 1998 Effects of growth hormone, activin, and follistatin on the development of preantral follicle from immature female mice. Endocrinology 139 2342-2347.

Lobie PE, Breipohl W, Garcia-Aragon J \& Waters MJ 1990 Cellular localization of the growth hormone receptor in the male and female reproductive systems. Endocrinology 126 2214-2221.

Lobie PE, Garcia-Aragon J, Wang BS, Baumbach WR \& Waters MJ 1992 Cellular localization of the growth hormone binding protein in the rat. Endocrinology 130 3057-3065.

Loveridge N \& Farquhuarson C 1993 Studies on growth plate chondrocytes in situ: cell proliferation and differentiation. Acta Paediatrica Scandinavica Supplement 391 42-48.

Lucy MC, Thatcher WW, Savio JD, Danet-Desnoyers G, Moser MT, Badinga L, Simmen FA \& Collier RJ 1992 Effect of bovine somatotropin on ovarian follicles, copora lutea, and embryos during early pregnancy in cattle. Journal of Animal Science 70 (Suppl 1) 271 (Abstract).

Lucy MC, Collier RJ, Kitchell ML, Dibner JJ, Hauser SD \& Krivi GG 1993a Immunohistochemical and nucleic acid analysis of somatotropin receptor populations in the bovine ovary. Biology of Reproduction 48 1219-1227.

Lucy MC, Hauser SD, Eppard PJ, Krivi GG, Clark JH, Bauman DE \& Collier RJ $1993 b$ Variants of somatotropin in cattle: gene frequencies in major dairy breeds and associated milk production. Domestic Animal Endocrinology 10 325-333.

Lucy MC, Thatcher WW, Collier RJ, Simmen FA, Ko Y, Savio JD \& Badinga L 1995 Effects of somatotropin on the conceptus, uterus, and ovary during maternal recognition of pregnancy in cattle. Domestic Animal Endocrinology 12 73-82.

Lucy MC, Boyd CK, Koenigfeld AT \& Okamura CS 1998 Expression of somatotropin receptor messenger ribonucleic acid in bovine tissues. Journal of Dairy Science $\mathbf{8 1} 1889-1895$. 
Lucy MC, Bilby CR, Kirby CJ, Yuan W \& Boyd CK 1999 Role of growth hormone in development and maintenance of follicles and corpora lutea. Journal of Reproduction and Fertility Supplement 54 49-59.

McCutcheon SN \& Davis SR 1991 Physiological responses to somatotropin in the ruminant. Journal of Dairy Science 74 (Suppl 2) 20-34.

McDowell GH, Hart IC \& Kirby AC 1987a Local intra-arterial infusion of growth hormone into the mammary glands of sheep and goats: effects on milk yield and composition, plasma hormones and metabolites. Australian Journal of Biological Science 40 181-189.

McDowell GH, Gooden JM, Leenanuruksa D, Jois M \& English AW $1987 b$ Effects of exogenous growth hormone on milk production and nutrient uptake by muscle and mammary tissues of dairy cows in mid-lactation. Australian Journal of Biological Science 40 295-306.

McFadden TH, Daniel TE \& Akers RM 1990 Effects of plane of nutrition, growth hormone, and unsaturated fat on mammary growth in prepubertal lambs. Journal of Animal Science $\mathbf{6 8}$ 3171-3179.

MacLeod JN, Worsley I, Ray J, Friesen HG, Liebhaber SA \& Cooke NE 1991 Human growth hormone variant is a biologically active somatogen and lactogen. Endocrinology 128 1298-1302.

Makarevich AV \& Sirotkin AV 1997 The involvement of the GH/ IGF-I axis in the regulation of secretory activity by bovine oviduct epithelial cells. Animal Reproduction Science 48 197-207.

Mason HD, Martikainen H, Beard RW, Anyaoko V \& Franks S 1990 Direct gonadotrophic effect of growth hormone on oestradiol production by human granulosa cells in vitro. Journal of Endocrinology 126 R1-R6.

Menashe Y, Sack Y \& Mashinach S 1991 Spontaneous pregnancies in two women with Laron-type dwarfism: are growth hormone and circulating insulin-like growth factor mandatory for induction of ovulation? Human Reproduction 6 670-671.

Mendoza C, Cremades N, Ruiz-Requena E, Martinez F, Ortega E, Bernabeu S \& Tesarik J 1999 Relationship between fertilization results after intracytoplasmic sperm injection, and intrafollicular steroid, pituitary hormone and cytokine concentrations. Human Reproduction 14 628-635.

Mepham TB, Lawrence SE, Peters AR \& Hart IC 1984 Effects of exogenous growth hormone on mammary function in lactating goats. Hormone and Metabolic Research 16 248-253.

Mercado M \& Baumann G 1994 A growth hormone/prolactinbinding protein in human milk. Journal of Clinical Endocrinology and Metabolism 79 1637-1641.

Mertani HC, Garcia-Caballero T, Lambert A, Gerard F, Palayer C, Boutin JM, Vonderhaar BK, Waters MJ, Lobie PE \& Morel G 1998 Cellular expression of growth hormone and prolactin receptors in human breast disorders. International Journal of Cancer 79 202-211.

Milsom SR, Breier BH, Gallaher BW, Cox VA, Gunn AJ \& Gluckman PD 1992 Growth hormone stimulates galactopoiesis in healthy lactating women. Acta Endocrinologica 127 337-343.

Mirlesse V, Frankenne F, Alsat E, Poncelet M, Hennen G \& Evain-Brion D 1993 Placental growth hormone levels in normal and pathological pregnancies. Pediatric Research 34 439-442.

Miura S \& Koida SS 1970 Effect of insulin and growth hormone on rat uterine RNA synthesis. Proceedings of the Society for Experimental Biology and Medicine 133 882-885.

Mizobuchi M, Downs TR \& Frohman LA 1995 Growth hormonereleasing hormone immunoreactivity in mouse placenta, maternal blood and amniotic fluid: molecular characterization and secretion from primary cell cultures in vitro. Endocrinology 136 1731-1736.

Mol JA, Henzen-Logmans SC, Hageman P, Misdorp W, Blankenstein MA \& Rijnberk A 1995a Expression of the gene encoding growth hormone in the human mammary gland. Journal of Clinical Endocrinology and Metabolism 80 3094-3096.
Mol JA, Van Garderen E, Selman PJ, Wolfswinkel J, Rijinberk A \& Rutteman GR 1995b Growth hormone mRNA in mammary gland tumors of dogs and cats. Journal of Clinical Investigation 95 2028-2034.

Mol JA, Van Garderen E, Rutteman GR \& Rijnberk A 1996 New insights in the molecular mechanism of progestin-induced proliferation of mammary epithelium: induction of the local biosynthesis of growth hormone $(\mathrm{GH})$ in the mammary glands of dogs, cats and humans. Journal of Steroid Biochemistry and Molecular Biology 57 67-71.

Mondschein JS, Canning SF, Miller DQ \& Hammond JM 1989 Insulin-like growth factors (IGFs) as autocrine/paracrine regulators of granulosa cell differentiation and growth. Biology of Reproduction 40 79-85.

Morales AJ 1997 Role of growth hormone in polycystic ovarian syndrome. Seminars in Reproductive Endocrinology 15 177-182.

Moretti C, Fabbri A \& Gnessi L 1990a Immunohistochemical localization of growth hormone-releasing hormone in human gonads. Journal of Endocrinological Investigation 13 301-305.

Moretti C, Bagnato A, Solan N, Franchez G \& Catt KJ 1990 b Receptor-mediated actions of growth hormone releasing factor on granulosa cell differentiation. Endocrinology 127 2117-2126.

Mori T, Saito H, Ohno Y, Irahara M, Hosoi E \& Saito S 1984 Evidence for existence of somatostatin-like immunoreactivity with molecular heterogeneity in porcine ovaries. Acta Endocrinologica 106 254-259.

Nagasawa H, Noguchi Y, Mori T, Niki K \& Namiki H 1985 Suppression of normal and preneoplastic mammary growth and uterine adenomyosis with reduced growth hormone level in SHN mice given monosodium glutamate neonatally. European Journal of Cancer and Clinical Oncology 21 1547-1551.

Nasagawa H, Hasegawa M, Yamamoto K, Sakamoto S, Mori T, Nagumo A \& Tojo H 1993 Normal and neoplastic growth of mammary glands and circulating levels of prolactin and growth hormone in mouse whey acidic protein promoter/human growth hormone $(\mathrm{mWAP} / \mathrm{hGH})$ transgenic mice. Zoological Science 10 963-970.

Newbold JA, Heap RB, Prosser CG, Phipps RH, Adriaens F \& Hard DL 1997 The effect of bovine somatotropin and diet on somatotropin binding sites in hepatic tissue of lactating dairy cows. Journal of Dairy Science 80 1085-1091.

Ng ST, Zhou J, Adesanya OO, Wang J, LeRoith D \& Bondy CA 1997 Growth hormone treatment induces mammary gland hyperplasia in aging primates. Nature Medicine 3 1141-1144.

Nickel BE \& Cattini PA 1992 Human placental growth hormone gene expression in rat pituitary tumour cells. 74th Annual Meeting of the Endocrine Society, San Antonio, TX. Abstract 36.

Nickel BE, Kardami E \& Cattini PE 1990 The human placental growth hormone variant is mitogenic for rat lymphoma $\mathrm{Nb} 2$ cells. Endocrinology 126 971-976.

Ogilvie S, Buhl WC, Olson JA \& Shiverick KT 1990 Identification of a novel family of growth hormone-related proteins secreted by rat placenta. Endocrinology 126 3271-3273.

Ogilvy-Stuart AL \& Shalet SM 1992 Commentary: Growth hormone and puberty. Journal of Endocrinology 135 405-406.

Ovesen P 1998 Synergistic effects of growth hormone and insulin-like growth factor-I on differentiation and replication of cultured human luteinized granulosa cells. Acta Obstetrica et Gynecologica Scandinavica 77 487-491.

Ovesen P, Ingerslev J, Orskov H \& Ledet T 1994 Effect of growth hormone on steroidogenesis, insulin-like growth factor-I (IGF-I) and IGF-binding protein-1 production and DNA synthesis in cultured human luteinized granulosa cells. Journal of Endocrinology $140313-319$

Owen EJ, Shoham Z, Mason BA, Ostergaard H \& Jacobs HS 1991 a Cotreatment with growth hormone after pituitary 
suppression for ovarian stimulation in in vitro fertilization: a randomized double-blind placebo-controlled trial. Fertility and Sterility 56 1104-1110.

Owen EJ, West C, Mason BA \& Jacobs HS $1991 b$ Cotreatment with growth hormone of sub-optimal responders in IVF-ET. Human Reproduction 6 524-528.

Ozawa K, Mizunuma H, Ozawa H \& Ibuki Y 1996 Recombinant human growth hormone acts on intermediate-sized follicles and rescues growing follicles from atresia. Endocrine Journal 43 87-92.

Paolucci M 1989 Estradiol receptor in the lizard liver. Seasonal changes and estradiol and growth hormone dependence. Molecular and Cellular Endocrinology 66 101-108.

Penarrubia J, Balasch J, Garcia-Bermudez M, Casamitjana R, Vanrell JA \& Hernandez E 2000 Growth hormone does not increase the expression of insulin-like growth factors and their receptor genes in the pre-menopausal human ovary. Human Reproduction $\mathbf{1 5}$ 1241-1246.

Peyon P, Baloche S \& Burzawa-Gerard E 1996 Potentiating effect of growth hormone on vitellogenin synthesis induced by 17 betaestradiol in primary cultures of female silver eel hepatocytes. General and Comparative Endocrinology 102 263-273.

Politis I, Block E \& Turner JD 1990 Effect of somatotropin on the plasminogen and plasmin system in the mammary gland: proposed mechanism of action for somatotropin on the mammary gland. Journal of Dairy Science 73 1494-1499.

Poretsky L, Grigorescu F, Seibel M, Moses AC \& Flier JS 1985 Distribution and characterization of insulin and insulin-like growth factor I receptors in normal human ovary. Journal of Clinical Endocrinology and Metabolism 61 728-734.

Postel-Vinay MC, Belair L, Kayser C, Kelly PA \& Djiane J 1991 Identification of prolactin and growth hormone binding proteins in rabbit milk. PNAS 88 6687-6690.

Powell MR \& Keisler DH 1995 A potential strategy for decreasing milk production in the ewe at weaning using a growth hormone release blocker. Journal of Animal Science 73 1901-1905.

Prosser CG, Royle C, Fleet IR \& Mepham TB 1991 The galactopoietic effect of bovine growth hormone in goats is associated with increased concentrations of insulin-like growth factor-I in milk and mammary tissue. Journal of Endocrinology 128 457-463.

Purup S, Sejrsen K, Foldager J \& Akers RM 1993 Effect of exogenous bovine growth hormone and ovariectomy on prepubertal mammary growth, serum hormones and acute in vitro proliferative response of mammary explants from Holstein heifers. Journal of Endocrinology 139 19-26.

Purup S, Sejrsen K \& Akers RM 1995 Effect of bovine GH and ovariectomy on mammary tissue sensitivity to IGF-I in prepubertal heifers. Journal of Endocrinology 144 153-158.

Quesnel H 1999 Localization of binding sites for IGF-I, insulin and GH in the sow ovary. Journal of Endocrinology 163 363-372.

Rabinovici J, Cataldo NA, Dandekar P, Rosenthal SM, Gargosky SE, Gesundheit N \& Martin MC 1997 Adjunctive growth hormone during ovarian hyperstimulation increases levels of insulin-like growth factor binding proteins in follicular fluid: a randomized, placebo-controlled, cross-over study. Journal of Clinical Endocrinology and Metabolism 82 1171-1176.

Rajkumar K, Kirkwood RN \& Thacker PA 1993 Effects of growth hormone on FSH, insulin and triiodothyronine-mediated estradiol production by granulosa cells from prepubertal gilts in vitro. Canadian Journal of Animal Science 73 443-447.

Ray J, Okamura H, Kelly PA, Cooke NE \& Liebhaber SA 1990 Human growth hormone variant demonstrates a receptor binding profile distinct from that of normal pituitary growth hormone. Journal of Biological Chemistry 265 7939-7944.

Rijnberk A \& Mol JA 1997 Progestin-induced hypersecretion of growth hormone: an introductory review. Journal of Reproduction and Fertility Supplement 51 335-338.

Ruan W, Catanese V, Wieczorek R, Feldman M \& Kleinberg DL 1995 Estradiol enhances the stimulatory effect of insulin-like growth factor-I (IGF-I) on mammary development and growth hormone-induced IGF-I messenger ribonucleic acid. Endocrinology 136 1296-1302.

Sakaguchi K, Tanaka M, Ohkubo T, Yoshizato H, Hanai Y, Fujikawa T, Kaneko H \& Nakashima K 1998 Tissue-specific regulation of growth hormone receptor and growth hormone binding protein gene expression during pregnancy and lactation in the rat. Endocrine Journal 45 (Suppl) S105-S107.

Samaras SE, Hagen DR, Bryan KA, Mondshein JS, Canning SF \& Hammond AC 1994 Effects of growth hormone and gonadotropin on the insulin-like growth factor system in the porcine ovary. Biology of Reproduction 50 178-186.

Sandles LK, Peel C \& Temple-Smith PD 1987 Mammary development and first lactation milk yields of identical twin heifers following prepubertal administration of bovine growth hormone. Animal Production 45 349-357.

Scanes CG \& Campbell RG 1995 Growth hormone: evolution. In Growth Hormone, pp 25-39. Eds S Harvey, CG Scanes \& WR Daughaday. Boca Raton: CRC Press.

Scanes CG \& Harvey S 1995 Growth hormone action: reproductive function. In Growth Hormone, pp 393-407. Eds S Harvey, CG Scanes \& WR Daughaday. Boca Raton: CRC Press.

Scaramuzzi RJ, Murray JF, Downing JA \& Campbell BK 1999 The effects of exogenous growth hormone on follicular steroid secretion and ovulation rate in sheep. Domestic Animal Endocrinology 17 269-277.

Schemm SR, Deaver DR, Griel LC \& Muller D 1990 Effects of recombinant bovine somatotropin on luteinizing hormone and ovarian function in lactating dairy cows. Biology of Reproduction $\mathbf{4 2}$ 815-821.

Schoenmakers I, Kooistra HS, Okkens AC, Hazewinkel HA, Bevers MM \& Mol JA 1997 Growth hormone concentrations in mammary secretions and plasma of the periparturient bitch and in plasma of the neonate. Journal of Reproduction and Fertility Supplement $\mathbf{5 1}$ 363-367.

Schwarzler P, Untergasser G, Hermann M, Dirnhofer S, Abendstein B, Madersbacher S \& Berger P 1997 Selective growth hormone/ placental lactogen gene transcription and hormone production in pre- and postmenopausal human ovaries. Journal of Clinical Endocrinology and Metabolism 82 3337-3341.

Scippo ML, Frankenne F, Igout A \& Hennen G 1991 Demonstration of the pituitary expression of the human $\mathrm{GH}-\mathrm{V}$ gene as assessed by a competitive hybridization technique. 73rd Annual Meeting Endocrine Society, Washington DC 72923.

Scippo ML, Frankenne F, Hooghe-Peters EL, Igout A, Velkeniers B \& Hennen G 1993 Syncytiotrophoblastic localization of the human growth hormone variant mRNA in the placenta. Molecular and Cellular Endocrinology 92 R7-R13.

Scott P, Kessler MA \& Schuler LA 1992 Molecular cloning of the bovine prolactin receptor and distribution of prolactin and growth hormone receptor transcripts in fetal and utero-placental tissues. Molecular and Cellular Endocrinology 89 47-58.

Sejrsen K \& Knight CH 1994 Unilateral infusion of growth hormone does not support a local galactopoietic action of growth hormone. Proceedings of the Nutrition Society 52 278A.

Sejrsen K, Foldager J, Sorensen MT, Akers RM \& Bauman DE 1986 Effect of exogenous bovine somatotropin on pubertal mammary development in heifers. Journal of Dairy Science 69 1528-1535.

Sejrsen K, Purup S, Vestergaard M, Weber MS \& Knight CH 1999 Growth hormone and mammary development. Domestic Animal Endocrinology 17 117-129.

Selman PJ, Mol JA, Rutteman GR \& Rijnberk A 1994 Progestin treatment in the dog. I. Effects on growth hormone, insulin-like growth factor I and glucose homeostasis. European Journal of Endocrinology 131 413-421.

Shaker AG, Yates RWS, Fleming R, Coutts JRT \& Jamieson ME 1992 Absence of effect of adjuvant growth hormone therapy on follicular responses to exogenous gonadotropins in women - normal and poor responders. Fertility and Sterility 58 919-923. 
Shamay A, Cohen M, Niwa M \& Gertler A 1988 Effect of insulin-like growth factor I on deoxyribonucleic acid synthesis and galactopoiesis in bovine undifferentiated and lactating mammary tissue in vitro. Endocrinology 123 804-809.

Shand JH \& West DW 1991 Effects of an antiserum to rat growth hormone and bromocriptine on cholesterol-metabolizing enzymes in the lactating rat mammary gland. Journal of Endocrinology 128 287-295.

Sharara FI \& Giudice LC 1997 Role of growth hormone in ovarian physiology and onset of puberty. Journal of the Society for Gynecologic Investigation 4 2-7.

Sharara FI \& Nieman LK 1994 Identification and cellular localization of growth hormone receptor gene expression in the human ovary. Journal of Clinical Endocrinology and Metabolism 79 670-672.

Sharara FI \& Nieman LK 1995 Growth hormone receptor messenger ribonucleic acid expression in leiomyoma and surrounding myometrium. American Journal of Obstetrics and Gynecology 173 814-819.

Sharara FI, Bhartiya D \& Nieman LK 1994 Growth hormone receptor gene expression in the mouse uterus: modulation by gonadal steroids. Journal of the Society for Gynecologic Investigation 1 285-289.

Shoham Z, Conway GS, Ostergaard H, Lahlou N, Bouchard P \& Jacobs HS 1992a Cotreatment with growth hormone for induction of spermatogenesis in patients with hypogonadotropic hypogonadism. Fertility and Sterility 57 1044-1051.

Shoham Z, Homburg R, Owen EJ, Conway SS, Ostergaard H \& Jacobs HS $1992 b$ The role of treatment with growth hormone in infertile patients. Baillieres Clinical Obstetrics and Gynecology 6 267-281.

Simpson ME, Marx W, Becks H \& Evans HM 1944 Effect of testosterone propionate on the body weight and skeletal system of hypophysectomized rats. Synergism with growth hormone. Endocrinology 35 309-316.

Simpson RB, Armstrong JD, Harvey RW, Miller DC, Heimer EP \& Campbell RM 1991 Effect of active immunization against growth hormone-releasing factor on growth and onset of puberty in beef heifers. Journal of Animal Science 69 4914-4924.

Singh H \& Thomas P 1993 Mechanism of stimulatory action of growth hormone on ovarian steroidogenesis in spotted seatrout, Cynoscion nebulosus. General and Comparative Endocrinology 89 341-353.

Singh H, Griffith RW, Takahashi A, Kawauchi H, Thomas P \& Stegeman JJ 1988 Regulation of gonadal steroidogenesis in Fundulus heteroclitus by recombinant salmon growth hormone and purified salmon prolactin. General and Comparative Endocrinology $\mathbf{7 2}$ 144-153.

Singtripop T, Mori T, Shiraishi K, Park MK \& Kawashima S 1993 Age-related changes in gonadotropin, prolactin and growth hormone levels with reference to the development of uterine adenomyosis in female SHN mice. In vivo 7 147-150.

Sirotkin AV 1996 Direct action of growth hormone on bovine ovarian cells: effects on estradiol, oxytocin, vasopressin release by granulosa cells and on oocyte maturation and cleavage in vitro. Annals of Endocrinology 57 219-224.

Sirotkin AV \& Makarevich AV 1996 The role of growth hormone and of cAMP-dependent intracellular mechanisms in the control of IGF-I, oxytocin and estradiol secretion by bovine granulosa cells. Journal of Reproduction and Fertility Supplement 17128.

Sirotkin AV \& Makarevich AV 1999 GH regulates secretory activity and apoptosis in cultured bovine granulosa cells through the activation of the cAMP/protein kinase A system. Journal of Endocrinology 163 317-327.

Sirotkin AV \& Nitray J 1994 Growth hormone and prolactin affect oxytocin, vasopressin, progesterone and cyclic nucleotide secretion by bovine granulosa cells in vitro. Journal of Endocrinology 143 417-422.
Sirotkin AV, Makarevic AV, Kotwica J, Marnet PG, Kwon HB \& Hetenyi L 1998 Isolated porcine ovarian follicles as a model for the study of hormone and growth factor action on ovarian secretory activity. Journal of Endocrinology 159 313-321.

Spencer GS, Robinson GM, Berry CJ \& Dobbie PM 1994 Alteration of maternal growth hormone levels during pregnancy influences both fetal and postnatal growth in rats. Biology of the Neonate 66 112-118.

Spencer TE, Gray A, Johnson GA, Taylor KM, Gertler A, Gootwine E, Ott TL \& Bazer FW 1999 Effects of recombinant ovine interferon tau, placental lactogen, and growth hormone on the ovine uterus. Biology of Reproduction 61 1409-1418.

Spicer LJ \& Echternkamp SE 1995 The ovarian insulin and insulinlike growth factor system with an emphasis on domestic animals. Domestic Animal Endocrinology 12 223-245.

Spicer LJ \& Stewart RE 1996 Interaction among bovine somatotropin, insulin and gonadotropins on steroid production by bovine granulosa and thecal cells. Journal of Dairy Science 79 813-821.

Spicer LJ, Alpizar E \& Echternkamp SE 1993 Effects of insulin, insulin-like growth factor-I, and gonadotrophins on bovine granulosa cell proliferation, progesterone production, estradiol production and insulin-like growth factor-I production in vitro. Journal of Animal Science 71 1232-1241.

Stanhope R, Albanese A, Hindmarsh P \& Brook CGD 1992 The effects of growth hormone therapy on spontaneous sexual development. Hormone Research 38 9-13.

Stelwagen K, Grieve DG, McBride BW \& Rehman JD 1991 Growth and subsequent lactation in primigravid Holstein heifers after prepartum bovine somatotropin treatment. Journal of Dairy Science $\mathbf{7 5}$ 463-471.

Stelwagen K, Grieve DG, Walton JS, Ball JL \& McBride BW 1993 Effect of prepartum bovine somatotropin in primigravid ewes on mammogenesis, milk production and hormone concentrations. Journal of Dairy Science 76 992-1001.

Sterle JA, Cantley TC, Lamberson WR, Lucy MC, Gerrard DE, Matteri RL \& Day BN 1995 Effects of recombinant porcine somatotropin on placental size, fetal growth, and IGF-I and IGF-II concentrations in pigs. Journal of Animal Science 73 2980-2985.

Stone BA \& Marrs RP 1992 Ovarian responses to menopausal gonadotropins in groups of patients with differing basal growth hormone levels. Fertility and Sterility 58 32-36.

Strowitzki T, Wiedemann R \& Hepp H 1991 Influence of growth factors EGF, IGF-I and human growth hormone on human endometrial stromal cells in vitro. Annals of the New York Academy of Sciences 626 308-311.

Takeda T \& Hashimoto H 1994 Effect of growth hormone on fetal and placental growth of spontaneous dwarf rat. Nippon Sanka Fujinka Gakkai Zasshi 46 581-587.

Talamantes F, Ogren L, Thordarson G \& Southard J 1988 The mouse placental lactogens. In Prolactin Gene Family and its Receptors, pp 145-154. Ed. K Hoshino. Amsterdam: Excerpta Medica.

Tamura M, Sasano H, Suzuki T, Fukaya T, Watanabe T, Aoki H, Nagura H \& Yajima A 1994 Immunohistochemical localization of growth hormone receptor in cyclic human ovaries. Human Reproduction 9 2259-2262.

Tapanainen J, Martikainen H, Voutilainen R, Orava M, Ruokonen A \& Ronnberg L 1992 Effect of growth hormone administration on human ovarian function and steroidogenic gene expression in granulosa-luteal cells. Fertility and Sterility 58 726-732.

Tauer LW \& Knoblauch WA 1997 The empirical impact of bovine somatotropin on New York dairy farms. Journal of Dairy Science $\mathbf{8 0}$ 1092-1097.

Tiong TS \& Herington AC 1991 Tissue distribution, characterization, and regulation of messenger ribonucleic acid for growth hormone receptor and serum binding protein in the rat. Endocrinology 129 $1628-1634$

Urbanek M, MacLeod JN, Cooke NE \& Liebhaber SA 1992 Expression of a human growth hormone $(\mathrm{hGH})$ receptor isoform is 
predicted by tissue-specific alternative splicing of exon 3 of the hGH receptor gene transcript. Molecular Endocrinology 6 279-287.

Urbanek M, Russell JE, Cooke NE \& Liebhaber SA 1993 Functional characterization of the alternatively spliced, placental human growth hormone receptor. Journal of Biological Chemistry 268 19025-19032.

Van der Kraak G, Rosenblum PM \& Peter RE 1990 Growth hormone-dependent potentiation of gonadotropin-stimulated steroid production by ovarian follicles of the goldfish. General and Comparative Endocrinology 79 232-239.

Van der Westerlaken LAJ, Van der Schans A, Eyestone WH \& Boer HA 1994 Kinetics of first polar body extrusion and the effect of time of stripping of the cumulus and time of insemination of developmental competence of bovine oocytes. Theriogenology 42 361-370.

Van Garderen E, de Wit M, Voorhout WF, Rutteman GR, Mol JA, Nederbragt H \& Misdorp W 1997 Expression of growth hormone in canine mammary tissue and mammary tumors. Evidence for a potential autocrine/paracrine stimulatory loop. American Journal of Pathology 150 1037-1047.

Vasilatos R \& Wangsness PJ 1981 Diurnal variations in plasma insulin and growth hormone associated with two stages of lactation in high producing dairy cows. Endocrinology 108 300-304.

Volpe A, Coukos G, Barreca A, Arini PG, Minuto F \& Giordano G 1989 Ovarian response to combined growth hormone-gonadotropin treatment in patients resistant to induction of superovulation. Gynecological Endocrinology 3 125-133.

Volpe A, Coukos G, Artini PG, Silferi M, Petraglia F \& Boghen F 1990 Pregnancy following combined growth hormone-pulsatile GnRH treatment in a patient with hypothalamic amenorrhea. Human Reproduction 3 345-347.

Volpe A, Artini PG, Barreca A, Minuto F, Coukos G \& Genazzani AR 1992 Effects of growth hormone administration in addition to gonadotrophins in normally ovulating women and polycystic ovary syndrome (PCO) patients. Human Reproduction 7 1347-1352.

Walden PD, Ruan W, Feldman M \& Kleinberg DL 1998 Evidence that the mammary fat pad mediates the action of growth hormone in mammary gland development. Endocrinology 139 659-662.

Wang HS \& Chard T 1999 IGFs and IGF-binding proteins in the regulation of human ovarian and endometrial function. Journal of Endocrinology 161 1-13.

Wang JJ 1989 Immunocytochemical demonstration of the binding of growth-related polypeptide hormones on chick embryonic tissue. Histochemistry 93 133-141.

Wathes DC, Perks CM, Davis AJ \& Denning-Kendall PA 1995 Regulation of insulin-like growth factor-I and progesterone synthesis by insulin and growth hormone in the bovine ovary. Biology of Reproduction $\mathbf{5 3} 882-889$.

Wilson ME, Gordon TP, Rudman CG \& Tanner JM 1989 Effects of growth hormone on the tempo of sexual maturation in female rhesus monkeys. Journal of Clinical Endocrinology and Metabolism 68 $29-38$.

Xu YP, Chedrese PJ \& Thacker PA 1995 Growth hormone amplifies insulin-like growth factor I induced progesterone accumulation and P450 scc mRNA expression. Molecular and Cellular Endocrinology 111 199-206.

Xu YP, Chedrese J \& Thacker PA 1997a Effects of GH on IGF-II induced progesterone accumulation by cultured porcine granulosa cells. Endocrine 7 157-163.

Xu YP, Chedrese PJ \& Thacker PA $1997 b$ Growth hormone as an amplifier of insulin-like growth factor-I action: potentiated oestradiol accumulation. Journal of Endocrinology 152 201-209.

Yallampalli C, Osuamkpe C \& Nagamani M 1992 Regulation of insulin-like growth factor I binding in the rat uterus by growth hormone and thyroxine. Journal of Reproduction and Fertility $\mathbf{9 4}$ 405-410.

Yallampalli C, Rajaraman S \& Nagamani M 1993 Insulin-like growth factor binding proteins in the rat uterus and their regulation by oestradiol and growth hormone. Journal of Reproduction and Fertility 97 501-505.

Yao J, Aggrey SE, Zadworny D, Hayes JF \& Kuhnlein U 1996 Sequence variations in the bovine growth hormone gene characterized by single-strand conformation polymorphism (SSCP) analysis and their association with milk production traits in Holsteins. Genetics 144 1809-1816.

Yao K 1993 Characterisation des recepteurs hepatiques de l'hormone de croissance (GH) chez la truite ar-en-ciel (Oncorhynchus mykiss) et etude preliminaire de leur regulation par le niveau d'alimentation et par la temperature. $\mathrm{PhD}$ Thesis, University of Rennes.

Yao K, Niu P, LeGac F \& Le Bail P 1991 Presence of specific growth hormone binding sites in rainbow trout (Oncorhynchus mykiss) tissues: characterization of the hepatic receptor. General and Comparative Endocrinology 81 72-82.

Yoshimura Y, Nakamura Y, Koyama N, Iwashita M, Adachi T \& Takeda Y 1993 Effects of growth hormone on follicle growth, oocyte maturation, and ovarian steroidogenesis. Fertility and Sterility 59 917-923.

Yoshimura Y, Iwashita M, Karube M, Oda T, Akiba M, Shiokawa S, Ando M, Yoshinaga A \& Nakamura Y 1994 Growth hormone stimulates follicular development by stimulating ovarian production of insulin-like growth factor-I. Endocrinology 135 887-894.

Young G \& Ball JN 1983 Ultrastructural changes in the adenohypophysis during the ovarian cycle of the viviparous teleost Poecilia latipinna. The growth hormone, adrenocorticotrophic, and prolactin cells and the pars intermedia. General and Comparative Endocrinology 52 86-101.

Younis JS, Dorembus D, Simon A, Schenker JG, Koren R \& Laufer N 1992 The effect of growth hormone supplementation on in vitro fertilization outcome: a prospective randomized placebo-controlled double-blind study. Fertility and Sterility 58 575-580.

Yuan W \& Lucy MC 1996a Effects of growth hormone, prolactin, insulin-like growth factors and gonadotropins on progesterone secretion by porcine luteal cells. Journal of Animal Science $\mathbf{7 4}$ 886-872.

Yuan W \& Lucy MC 19966 Messenger RNA expression for growth hormone receptor, luteinizing hormone receptor, and steroidogenic enzymes during the estrous cycle and pregnancy in porcine and bovine corpora lutea. Domestic Animal Endocrinology 13 431-444.

Yuan W, Sterle JA, Cantley TC, Lamberson WR, Day BN \& Lucy MC 1996 Responses of porcine corpora lutea to somatotropin administration during pregnancy. Journal of Animal Science $\mathbf{7 4}$ 873-878.

Zachmann M 1992 Interrelations between growth hormone and sex hormones - physiology and therapeutic consequences. Hormone Research 38 1-8.

Zebrowska T, Siadkowska E, Zwierzchowski L, Gajewska A \& Kochman K 1997 in vivo effect of growth hormone on DNA synthesis and expression of milk protein genes in the rabbit mammary gland. Journal of Physiology and Pharmacology 48 825-837.

de Zegher F, Vanderschueren-Lodeweyckx M, Spitz B, Faijerson Y, Blomberg F, Beckers A, Hennen G \& Frankenne F 1990 Perinatal growth hormone $(\mathrm{GH})$ physiology: effect of $\mathrm{GH}-$ releasing factor on maternal and fetal secretion of pituitary and placental GH. Journal of Clinical Endocrinology and Metabolism 71 520-522.

Zuelke KA \& Brackett BG 1993 Increased glutamine metabolism in bovine cumulus cell-enclosed and denuded oocytes after in vitro maturation with luteinizing hormone. Biology of Reproduction 48 815-820.

Received 30 May 2000

Revised manuscript received 16 August 2000 Accepted 6 September 2000 